\title{
Fission yeast genes that confer resistance to staurosporine encode an AP-1-like transcription factor and a protein kinase related to the mammalian ERK1/MAP2 and budding yeast FUS3 and KSS1 kinases
}

\author{
Takashi Toda, ${ }^{1}$ Mizuki Shimanuki, and Mitsuhiro Yanagida \\ Department of Biophysics, Faculty of Science, Kyoto University, Kitashirakawa-Oiwake, Sakyo-ku, Kyoto 606, Japan
}

\begin{abstract}
Staurosporine, a potent inhibitor of protein kinase $C$, arrests fission yeast cell elongation specifically at a stage immediately after cell division. We isolated two genes, which, when carried on multicopy plasmids, confer drug resistance in fission yeast. One, $s p k 1^{+}$, encodes a protein kinase highly similar (54\% identity) to those encoded by the mammalian ERK1/MAP2 kinase and the budding yeast KSS1 and FUS3 genes. It is not essential for vegetative growth of Schizosaccharomyces pombe cells but is required for conjugation. The spk1+ gene product is a 45-kD protein enriched in the nucleus, and its level increases 10-fold after addition of staurosporine. The other gene pap $1^{+}$encodes an AP-1-like transcription factor that contains a region rich in basic amino acids followed by a "leucine zipper" motif. The pap $1^{+}$gene is required for $s p k 1^{+}$-conferred staurosporine resistance. These two genes appear to function as a part of the fission yeast growth control pathway.
\end{abstract}

[Key Words: Fission yeast; staurosporine; inhibitor of protein kinase C; AP-1-like factor; protein kinase; growth control]

Received July 17, 1990; revised version accepted November 12, 1990.

In the rapidly dividing cells of the early embryo, the cell cycle consists of basically only $S$ and $M$ phases, $G_{1}$ and $\mathrm{G}_{2}$ being absent. These cells have little time to grow so that their size is reduced by the cycles of division. On the other hand, somatic cells grow during interphase, and after reaching certain critical cell volume, enter mitosis and divide. Therefore, in eukaryotic growth control, two classes of switches for cell division may exist, namely, entry into the growing stage and exit from that stage.

Mitogens trigger resting, quiescent cells to enter the cell division cycle, through complex networks involving protein phosphorylation/dephosphorylation (for review, see Edelman et al. 1987; Cohen 1989). Several oncogenes are known to encode tyrosine- or serine/threonine-specific protein kinases (for review, see Bishop 1985). Tumor promoters such as TPA, an activator of PKC (Nishizuka 1986), and some mitogens exert their biological effect by activating transcription of a series of genes, known as TPA- or serum-inducible genes. The nuclear oncogenes c-jun and c-fos are two such genes and form a heterodimer complex with each other, referred to as AP-1 (Angel et al. 1987, 1988; Bohmann et al. 1987). The

${ }^{1}$ Corresponding author. link between the protein phosphorylation cascade and the activation of nuclear transcription factors, however, remains unclear.

There are two distinct stages for growth and division in the cell cycle of the fission yeast Schizosaccharomyces pombe (Mitchison 1970). The rod-like cells extend continuously for the three-quarters of the cell division cycle (Fig. 1D). In the following constant cell-length stage, mitosis, septation, DNA synthesis, and cytokinesis occur (the $G_{1}$ phase is negligible in exponentially growing wild-type yeast in rich media). Growth (i.e., cell elongation) apparently ceases at the constant cell-length stage; the growing stage of wild-type $S$. pombe cells is restricted to the $G_{2}$ phase. Thus, after the completion of cell division the early $G_{2}$ cells begin to grow immediately.

The $S$. pombe genes involved in the exit from $\mathrm{G}_{2}$ and the entry into $M$ phase have been well documented in recent years and shown to be conserved in higher eukaryotes. They include the $c d c 2^{+}$protein kinase [a component of $\mathrm{M}$ phase-promoting factor $(\mathrm{MPF})], \mathrm{cdc} 13^{+}$(a cyclin homolog), and $s u c 1^{+} \mathrm{p} 13$. The products of $c d c 25^{+}$ (a mitotic inducer), wee $1^{+}$(a protein kinase, putative mitotic inhibitor), and nim $1^{+}$(a protein kinase, putative mitotic inducer; for review, see Nurse 1990) genes may also control the timing of entry into mitosis. The entry 
into the $\mathrm{M}$ phase is blocked in $c d c 2, c d c 13$, and $c d c 25$ mutants but cell elongation is not. In contrast, none of the genes involved in the initiation of cell elongation after cell division have been identified in this organism. No mutant has been isolated that exhibits an arrest phenotype specifically at the entry into the cell-elongation phase. Either such specific controlling genes do not exist or they may be functionally redundant, mutations in them not resulting in the arrest phenotype.

Staurosporine, an alkaloid compound produced in Streptomyces staurospores and originally found as an antifungal agent, has been shown to possess a very strong cytotoxicity when applied to some mammalian tumor cell lines (Omura et al. 1977; Tamaoki et al. 1986). It has been shown that the drug is one of the most potent inhibitors for $\mathrm{PKC}$ in vitro $\left(\mathrm{IC}_{50}=2.7 \mathrm{nM}, \mathrm{Ta}\right.$ maoki et al. 1986). The drug also inhibits other protein kinases, including cyclic nucleotide-dependent protein kinases (protein kinases $A$ and G) and src tyrosine-specific protein kinase, although the extent of inhibition for those kinases is severalfold lower than that for PKC (Nakano et al. 1987).

Recently the isolation of a PKC-like gene from the budding yeast Saccharomyces cerevisiae was reported (Levin et al. 1990), as was the purification of a PKC-like activity from that yeast (Ogita et al. 1990). We have undertaken the isolation of mutants that show an altered sensitivity to staurosporine, expecting that some of them would be derived from PKC or other kinase gene homologs (Toda and Yanagida et al. 1988). In this paper we will demonstrate that a low concentration of staurosporine arrests $S$. pombe cells at a specific cell-cycle stage immediately after cytokinesis. Subsequently, we have identified 11 genetic loci that display hypersensitivity to the drug. Using these mutants, we have obtained two genes that, when carried on a multicopy plasmid, confer drug resistance even to the wild-type cells. Nucleotide sequence determination and biochemical analysis indicate that one gene codes for a novel protein kinase and the other gene, surprisingly, encodes an AP-1-like transcription factor. The possible implications of these findings are discussed.

\section{Results}

Staurosporine arrests growth of $\mathrm{S}$. pombe

To examine the effect of staurosporine on the growth of the fission yeast $S$. pombe, the drug $(0.5 \mu \mathrm{g} / \mathrm{ml})$ was added to an exponentially growing asynchronous culture. Most cells divided once and then arrested. Hence, the average cell length in the culture was strikingly reduced from $10.1 \mu \mathrm{m}$ at $0 \mathrm{hr}$ to $7.6 \mu \mathrm{m}$ at $3 \mathrm{hr}$ after addition of the drug (Fig. 1A). Consistently, the percentage of septated cells decreased from $13 \%$ to $1 \%$. Prolonged incubation caused cells to become fragile and lyse. Drugtreated cells lost viability (the percentage of viable cells was $14 \%$ and $4.7 \%$ after 3 and $6 \mathrm{hr}$, respectively). In contrast, stationary-phase cells were insensitive to the drug (viability was $100 \%$ in a drug concentration of $1 \mu \mathrm{g} / \mathrm{ml}$ ).
These results suggested that staurosporine inhibited cell elongation in actively growing cells.

To determine whether small cells immediately after cell division are specifically sensitive to the drug, synchronous culture analysis (Mitchison 1988) was done in the presence of the drug. Growing wild-type cells were fractionated by centrifugal elutriation, and the small, selected $G_{2}$ cells were regrown in a rich YPD medium in the presence of the drug (Fig. 1B). The cell number and size were monitored for the following $3 \mathrm{hr}$. Cell elongation and division did not take place; the average cell lengths were 7.1 and $7.6 \mu \mathrm{m}$ after $0 \mathrm{hr}$ and $3 \mathrm{hr}$, respectively (Fig. 1B). In contrast, if the drug was added $60 \mathrm{~min}$ after the generation of synchrony when the average cell length had reached $10.4 \mu \mathrm{m}$, cells divided once within the following $80 \mathrm{~min}$ and then remained as small cells (average cell length, $7.4 \mu \mathrm{m}$ ) as shown in Figure 1C. As illustrated in Figure 1D, effect of staurosporine is dependent on the cell-cycle stage; cells immediately after division seem to become sensitive to the drug.

\section{Genetic loci and genomic DNAs that affect staurosporine sensitivity}

Wild-type $S$. pombe cells are capable of forming colonies on a solid medium containing $0.3 \mu \mathrm{g} / \mathrm{ml}$ of staurosporine. We used this criteria to isolate $S$. pombe mutants that are supersensitive to staurosporine, by replica-plating $\sim 200,000$ mutagenized colonies and selecting for mutants that were unable to grow on the plates containing $0.2 \mu \mathrm{g} / \mathrm{ml}$ staurosporine. Eighteen strains (ss1-ss18; see Materials and methods) were obtained and crossed with a mater strain, and the drug sensitivity of heterozygous diploids was examined. All of the mutants were recessive. Complementation tests by pairwise crosses showed that these mutants defined 11 loci (Table 1; designated sts1-sts11 for staurosporine supersensitive), indicating that staurosporine sensitivity is genetically complex.

During the course of isolating genes that suppress the sts mutations, we obtained two plasmids (pST1 and pST23) that suppress the drug supersensitivity of all the sts mutations except sts1 (Table 1; for details, see Materials and methods). Furthermore, these two plasmids even conferred drug resistance to wild-type cells. Transformants containing these plasmids produce colonies in the presence of $1.0-1.5 \mu \mathrm{g} / \mathrm{ml}$ drug. pST23 confers resistance more effectively than pST1 (Table 1).

\section{pST23 encodes a novel protein kinase}

Determination of the nucleotide sequence of the $4.0-\mathrm{kb}$ Sall fragment in pST23 (Fig. 2A) indicated one long open reading frame (ORF) that potentially encodes a polypeptide of 372 amino acids (Fig. 2B; see Materials and methods). The predicted amino acid sequence contains consensus sequences of known protein kinases, as shown in Figure 2B for the ATP-binding site (O) and for the invariant kinase consensus (O) (Hanks et al. 1988).

A computer search for homologous proteins showed 
that this putative protein kinase is homologous to a number of protein kinases, with the highest homology (54\% identity) to the products of the S. cerevisiae KSS1 and FUS3 genes that are proposed to be involved in the growth signal transduction pathway (Courchesne et al. 1989; Elion et al. 1990) and to a lesser extent (37\%) to the human and yeast $c d c 2^{+} / C D C 28$ protein kinases (Lee and Nurse 1987). We designated the gene for this novel protein kinase $s p k 1^{+}$(staurosporine-related protein $\underline{\mathrm{ki}}$ nase 1 ).

Very recently, the mammalian ERK1 or MAP2 kinase was cloned and reported to be homologous to KSS1 and FUS3 (Boulton et al. 1990). spk $1^{+}$is also very homologous $(54 \%)$ to ERK1. spk $1^{+}$seems to be equally homologous to ERK1, KSS1, or FUS3; the amino acid identity between any combination of the four proteins is $54 \%$. There are two regions where the amino acid sequences of ERK1, KSS1, and FUS3 are quite divergent; namely a short stretch located between subdomains VII and VIII, and the carboxy-terminal 50-amino acid residues (Fig. 2C; Boulton et al. 1990; Elion et al. 1990). The amino acid sequence of $s p k 1^{+}$in these regions is also very different from that of the other proteins, although the carboxy-terminal 20 amino acids of $s p k 1^{+}$have some weak homology with those of ERK1 and FUS3 (Fig. 2C). Note that these two divergent regions do not have any homology with those of $c d c 2^{+} / C D C 28$, either. The remaining regions are very homologous among $s p k 1^{+}$, ERK1, KSS1, and FUS3.

\section{The spk $1+$ gene is nonessential but required for conjugation}

To determine whether $\operatorname{spk} 1^{+}$is an essential gene, onestep gene disruption (Rothstein 1983) was done. A Uradiploid was constructed and transformed with the disrupted spk1:: ura4 ${ }^{+}$sequence (Materials and methods). The transformant was sporulated in a poor medium, and tetrad analysis was carried out. Four viable spores were obtained $\left(\mathrm{Ura}^{+} / \mathrm{Ura}^{-}\right.$, segregated $\left.2: 2\right)$, indicating that the $s p k 1^{+}$gene is nonessential. As confirmation, Southern hybridization of genomic DNAs of each of the four tetrad segregants was done, and Ura ${ }^{+}$segregants showed the expected disruption pattern (data not shown). The disrupted cells grew apparently normally and showed little difference in staurosporine sensitivity in comparison with wild-type cells (Table 1). However,

Figure 1. Effect of staurosporine on growth of $S$. pombe cells $(A-C)$ Cell size distribution in $S$. pombe culture treated with staurosporine. Each histogram represents size distribution patterns before (top) and after drug addition (bottom; $A$ and $B, 3 \mathrm{hr} ; C, 2 \mathrm{hr})$. Staurosporine $(0.5$ $\mu \mathrm{g} / \mathrm{ml}$ ) was added to exponentially grown cells $(A)$ or elutriated small synchronized cells at $0(B)$ or $1 \mathrm{hr}$ after the synchronous culture $(C)$. Values shown (upper right) represent average cell length in micrometers. Note that during a 1 -hr incubation of the synchronous culture, small cells grew and elongated from 7.1 to $10.4 \mu \mathrm{m}$ (cf. top panels in $B$ and $C$ ). In any of the three conditions, cells were arrested by the drug at a small cell size just after cell division. At least 100 cells were measured for each sample. $(D)$ Schematic drawings of wild-type $S$. pombe cell size growing in a rich medium and the effect of staurosporine on its cell elongation are illustrated. The generation time is $\sim 130 \mathrm{~min}$ in the rich YPD medium at $33^{\circ} \mathrm{C}$. Small cells were collected immediately after cell division and grown synchronously (Mitchison 1988). Thin arrows indicate the time points when staurosporine $(0.5$ $\mu \mathrm{g} / \mathrm{ml}$ ) was added to the synchronous culture $(0$ and $1 \mathrm{hr}$, respectively). Open horizontal arrows show the arrested stages of each sample after a $3-\mathrm{hr}$ incubation $(B$ and $C$; for details, see text). Note that small cells arrested almost instantly, whereas cells to which staurosporine was added after a 1-hr incubation divided once and then arrested.

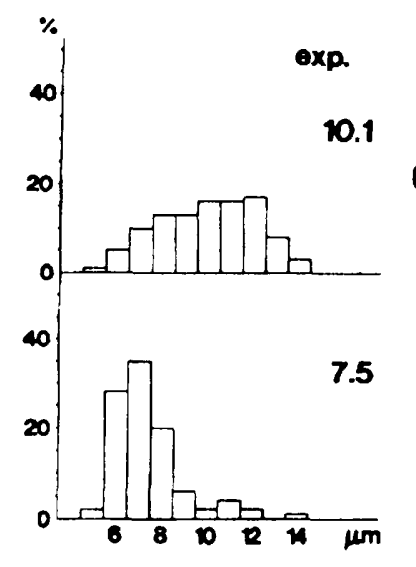

B

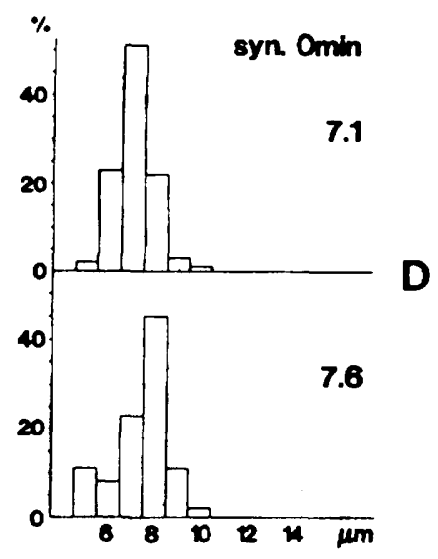

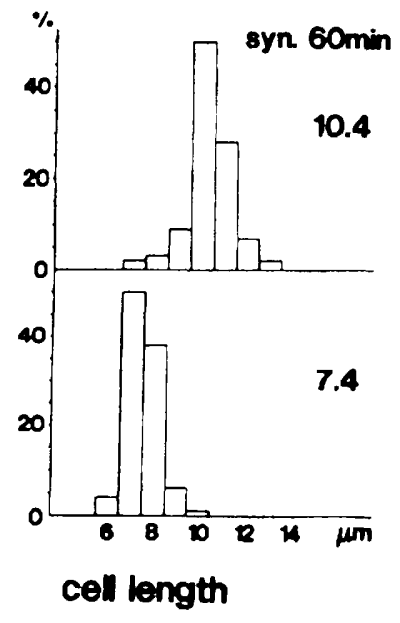

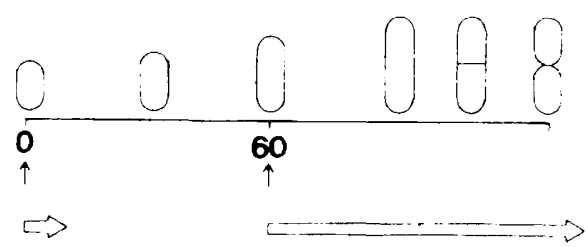


Table 1. Growth of transformants containing multicopy plasmid in the presence of staurosporine

\begin{tabular}{|c|c|c|c|c|c|}
\hline \multirow[b]{2}{*}{$\begin{array}{l}\text { Loci } \\
\text { number }\end{array}$} & \multirow[b]{2}{*}{$\begin{array}{l}\text { Number of } \\
\text { alleles }\end{array}$} & \multirow{2}{*}{$\begin{array}{l}\text { Drug } \\
\text { concentration } \\
(\mu \mathrm{g} / \mathrm{ml})\end{array}$} & \multicolumn{3}{|c|}{ Plasmids } \\
\hline & & & $\begin{array}{l}\mathrm{pDB} 248 \\
\text { (vector) }\end{array}$ & $\begin{array}{c}\mathrm{pST} 1 \\
\left(\text { pap }^{+}\right)\end{array}$ & $\begin{array}{l}\text { pST23 } \\
\mid \text { spk1 }{ }^{+} \mid\end{array}$ \\
\hline \multirow{6}{*}{$\begin{array}{l}\text { Wild-type/ } \\
\text { spk1- }\end{array}$} & & 0.2 & + & + & + \\
\hline & & 0.3 & + & + & + \\
\hline & & 0.5 & - & + & + \\
\hline & & 1.0 & - & $+/-$ & + \\
\hline & & 1.5 & - & - & $+1-$ \\
\hline & & 2.0 & - & - & - \\
\hline \multirow{6}{*}{ pap1- } & & 0.2 & - & + & - \\
\hline & & 0.3 & - & + & - \\
\hline & & 0.5 & - & + & - \\
\hline & & 1.0 & - & $+1-$ & - \\
\hline & & 1.5 & - & - & - \\
\hline & & 2.0 & - & - & - \\
\hline sts1 & 5 & 0.2 & - & - & - \\
\hline sts2 & 4 & 0.2 & - & + & + \\
\hline sts3 & 3 & 0.2 & - & + & + \\
\hline sts 4 & 1 & 0.2 & - & + & + \\
\hline sts5 & 1 & 0.2 & - & + & + \\
\hline sts 6 & 1 & 0.2 & - & + & + \\
\hline sts 7 & 1 & 0.2 & - & NT & + \\
\hline sts 8 & 1 & 0.2 & - & + & + \\
\hline sts 9 & 1 & 0.2 & - & + & $+1-$ \\
\hline sts 10 & 1 & 0.2 & - & + & NT \\
\hline sts11 & 1 & 0.2 & - & + & + \\
\hline
\end{tabular}

HM123, TP106-3C, and TP108-3C were used as wild-type, spk1-, and pap1- cells for each transformation, respectively. The relative staurosporine sensitivity was determined by streaking each transformant on YPD plates containing $0.2-2.0 \mu \mathrm{g} / \mathrm{ml}$ of the drug and those transformants which, after 3 days incubation at $33^{\circ} \mathrm{C}$, formed normal-sized colonies were judged to be growing (represented by $+\mid$ and small colonies $(+|-|$ and those that did not form colonies were described as no growth $|-|$. Note that the plasmid pST23 that carries the $\operatorname{spk} 1^{+}$gene can not confer staurosporine resistance in pap1- cells. (NT) Not tested.

we found that $s p k 1^{-}$cells, whichever mating type they were, had very low mating ability. In the homothallic $h^{90}$ spk $1^{-}$cells, we have never observed any diploids or asci. In contrast, in the isogenic wild-type $h^{90}$ strain, we found $>10^{4}$ diploids and asci. The sterile phenotype is suppressed by transforming the disrupted cells with plasmids containing the intact $s p k 1^{+}$gene.

\section{The $\mathrm{spk1} 1^{+}$gene product is a nuclear kinase}

We raised antiserum against fused $s p k 1^{+}$protein (Materials and methods) and identified the product of $s p k 1^{+}$ gene in the $S$. pombe extracts by immunoprecipitation (Fig. 3A). A protein band of $45 \mathrm{kD}$ was detected by immunoblotting only when using concentrated affinity-purified anti-spkl antibodies (lane 3 ) and not with diluted serum (lane 2) nor preimmune serum (lane 1). When the $\mathrm{ADH}$ (alcohol dehydrogenase) promoter (Russell and Hall 1983) was connected with the coding sequence of the $s p k 1^{+}$gene to overproduce the protein (Materials and methods), we found $>10$-fold overproduction of a protein band of $43 \mathrm{kD}$ (lanes 5 and 6). An In vitro protein kinase assay was performed with anti-spk1 immunoprecipitates using histone $\mathrm{Hl}$ as a substrate. After incubation with $\left[\gamma^{-32} \mathrm{P}\right] \mathrm{ATP}$, reaction mixtures were run in SDS-PAGE. We found that histone H1 was specifically phosphorylated in immune complexes prepared from wild-type cell extracts (Fig. 3B, lanes 1 and 2) but not at all in those from spk1- (lanes 3 and 4). No endogenous proteins were phosphorylated even after prolonged exposure (data not shown). This result clearly demonstrates that the $s p k 1^{+}$gene product has a protein kinase activity for histone $\mathrm{Hl}$ as predicted from its nucleotide sequence. We tested casein as an alternate substrate. Although immunoprecipitates prepared from either wildtype or spk1- extracts seemed to contain a weak casein kinase activity, little difference, if any, was detected between the two extracts (lanes 5 and 6).

To determine the cellular localization of the $s p k 1^{+}$ protein, indirect immunofluorescence microscopy was performed using affinity-purified anti-spk1 antibodies. As shown in Figure 4, A and B, in cells carrying $\mathrm{ADH}$ promoter expression of the $s p k 1^{+}$gene, immunofluorescence was observed primarily within the nucleus and occasionally in the unidentified organelles other than nuclei. On the other hand, when cells carrying only vector plasmids were used, immunofluorescence was very faint, presumably due to the low level of the $s p k 1^{+}$ protein (data not shown). Fractionation of cellular components of $S$. pombe homogenates of cells containing a single-copy chromosomal spk $1^{+}$gene by Percoll gradient centrifugation (Hirano et al. 1988) indicated that 
the $s p k 1^{+}$protein was broadly distributed throughout the fractions but preferentially accumulated in the nuclear fractions (data not shown).

\section{Staurosporine induces synthesis of the $\mathrm{spk} \mathrm{1}^{+}$protein}

We addressed the issue of whether the addition of staurosporine affected the levels of the $s p k 1^{+}$gene product in $S$. pombe cells. If the $s p k 1^{+}$protein kinase is directly or indirectly related to staurosporine inhibition, a feedback mechanism might exist to counteract the drug and thereby induce overproduction of the $s p k 1^{+}$kinase. Wild-type cells were grown exponentially and transferred to medium containing $0.5 \mu \mathrm{g} / \mathrm{ml}$ staurosporine. Aliquots of the culture were taken at intervals, and their extracts were analyzed by SDS-PAGE and immunoblotting using affinity-purified anti-spk 1 antibody.

As shown in Figure 3C, it was evident that the level of the $s p k 1^{+}$protein was increased by the drug; induction became clear 80 min after drug addition. Quantitative measurement of the amount of the protein showed that the $s p k 1^{+}$protein was induced $\sim 10$-fold 120 min after drug addition. Induction does not seem merely to be a consequence of growth arrest caused by the drug because the induction can be seen at levels as low as $0.3 \mu \mathrm{g} / \mathrm{ml}$ staurosporine (Fig. 3D), the level at which cells apparently grow and divide normally. Not all protein kinases are induced by the drug; for example, the level of the $c d c 2^{+}$kinase does not change at all during drug treatment (data not shown).

\section{Nucleotide and predicted amino acid sequences of $\mathrm{papl}^{+}$gene}

By subcloning pST1, a minimal complementing sequence was restricted to a $2.5-\mathrm{kb}$ HindIII fragment (Fig. $5 \mathrm{~A}$, and its nucleotide sequence was determined by the dideoxy method (Sanger et al. 1977). We found one ORF that encodes a protein of 544 amino acids beginning from a putative initiator methionine (Fig. 5B).

Analysis of the predicted amino acid sequence of $\mathrm{pST} 1$ indicated that it is likely to be a transcription factor similar to c-jun and c-fos. As shown in Figure 5B, the deduced sequence contains a "leucine zipper motif" in which leucine residues appear at every seventh position with the exception of threonine, which appears at the third position. A basic domain adjacent to the leucine repeat similar to that found in c-jun, c-fos, and GCN4 (Landschulz et al. 1988) is also present in the pST1 sequence. The homology between the basic regions of these proteins is $\sim 40 \%$ if conservative replacements of amino acids are considered to be the same (Fig. 5D).

The basic region of pST1 particularly resembles that found in the recently identified S. cerevisiae YAP1 protein la yeast AP-1-like gene; Harshman et al. 1988; Moye-Rowley et al. 1989); 19 of 29 amino acids in the basic regions are identical (Fig. $5 \mathrm{C}, \mathrm{D}$ ). Note that the third position of the leucine repeat in YAP1 is also not leucine, but asparagine. Furthermore, comparison of the two sequences shows that there is one additional homol- ogous region, the carboxy-terminal 50-residue-long stretch (Fig. 5C) in which 50\% homology is observed (25 of 50 amino acids are identical; Fig. $5 \mathrm{E}$ ). It is worth noting, however, that the carboxy-terminal region is not essential to confer drug resistance; a truncated pap $1^{+}$ protein lacking the carboxyl domain produced drug resistance (Fig. 5A). We designated the gene pap $1^{+}$(pombe AP-1-like gene 1). Jones and co-workers (1988) had previously identified an AP-1-like activity in fission yeast nuclear extract. We determined whether the isolated pap $1^{+}$product behaved as an AP-1-like protein.

\section{Specific binding of pap $1^{+}$to AP-1 site}

Approximately $80 \%$ of the pap $1^{+}$-coding sequence was expressed in Escherichia coli using a T7 RNA polymerase-dependent promoter [kindly provided by F.W. Studier (Studier and Moffatt 1986); see Materials and methods]. Note that when the same portion of pap $1^{+}$ was expressed in $S$. pombe using the strong ADH promoter (Russell and Hall 1983), it conferred drug resistance (Fig. 5A). Using gel-purified fusion proteins, we examined the in vitro interaction between a DNA sequence containing an AP-1 binding site (Angel et al. 1987) and the pap1 ${ }^{+}$gene product. We made oligonucleotides that contain an AP-1-binding site of human collagenase and SV40 early promoter (called Col-AP-1 and SV-AP-1, respectively; Jones et al. 1988). We also made two other oligonucleotides (Col-mutl and Colmut2) that had point mutations in essential nucleotides of Col-AP-1 (Fig. 6A; Angel et al. 1987).

Gel retardation assays were done as described in Materials and methods. The pap $1^{+}$protein was effectively bound to Col-AP-1 when it was used as a labeled probe (Fig. 6B, lane 2). It binds similarly to SV-AP-1 (data not shown). Binding of these labeled probes was entirely competed out by the addition of a 400-molar excess of either cold Col-AP-1 or SV-AP-1 (lanes 3 and 4). In contrast, mutated AP-1 oligonucleotides (Col-mut1 or Colmut2) were totally ineffective in competing with the intact AP-1 oligonucleotides (lanes 5 and 6). A DNase I footprinting experiment using the SV40 promoter/enhancer region as a probe confirmed that binding of the pap $1^{+}$protein to these sequences was specific to the AP-1 site (Fig. 6C). These biochemical characters are in exact parallel with those reported by Jones et al. (1988). Therefore, we believe that the isolated pap $1^{+}$gene encodes a fission yeast AP-1-like factor or at least one of those factors.

\section{Disruption of the papl ${ }^{+}$gene}

The method for one-step gene replacement (Rothstein 1983) was used to disrupt the wild-type pap $1^{+}$gene (Materials and methods). Upon sporulation of $\mathrm{Ura}^{+}$heterozygous diploids, we obtained four viable spores for all tetrads examined. The uracil marker segregated $2^{+}: 2^{-}$. Disruption of the pap $1^{+}$gene in the $\mathrm{Ura}^{+}$segregants was confirmed by Southern blotting (data not shown). Although the deleted pap1- segregants were viable, the 
Fission yeast AP-1-like factor and protein kinase

A

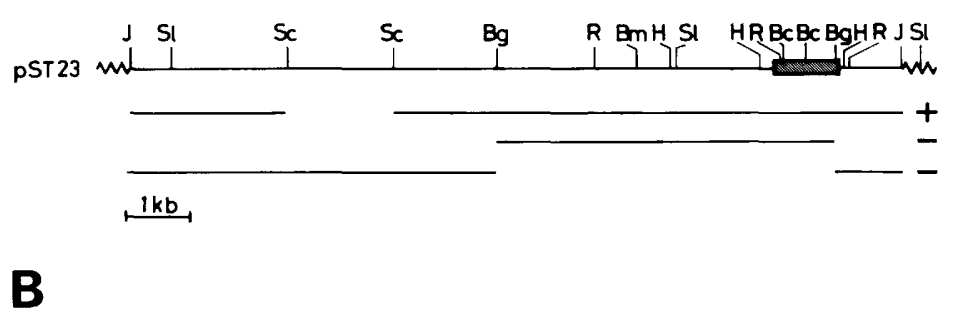

GTCGACTCCCA

GCATGTTCGTCTTCCAATATCTCGATCATTTGCTCCCGTGATATAGACCGAATCGTTAACAATTCATCAATCCTTGCTTGAAACCACTTTTCATGCTCCTCTGTCCATGCATCCTTTCTT TTCT TTGCATTGAAAGAGTTTGTGCTTTCAACT TTGCT TTCAGAATCGTCAGAAGAGGATCGCGCAATTTTACGCTTTGATGCATGATCACTACATGTTTTTGACAACGACAGAGGAAAGT GGACTATTTTCCAATAACTGTCGTGTAGCTTCCATACAATCTTTATGGTCATCTGACACAGGCTCACTAGTTCCTCCTAAGGAGTGAGCACCGTGAAGGCTTATGTATAAGTGACCCCAT

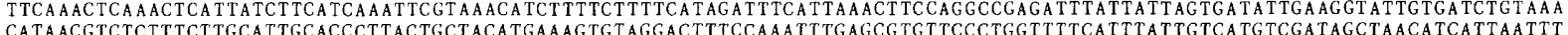
CATAACGTCTCTTTCTTGCATTGCACCCTTACTGCTACA TGAAAGTGTAGGACTTTCCAAATTTGAGCG TGTTCCCTGGTTTTCATTTAT TG TCA TGTCGA TAGCTAACATCA TTAATTT ACAATGCCT TCTAATAACGGGT TAGCCAATTCA TGA TGA AGTAAGGACGCCAAGGGAAATTTATGAATGTTTAACTATTTT TG TTGAGAGT TTCAACGGATTTATCTATTTTTTTTCAT GCTTTTTAAACTTTCATAAGATTATTATTACGAGAACATAAAATTAAACAACCATCATACGGT TTCTGTTCAACCTCTTCAAGAACCCATTCAAATATGCTTGCATAAGCAATTGTTTCT GCT TACCT TGT AAATTAATTATTTCGATTTAGATAGTCT TAAAATATTGCATTTCTTTGCCT TTAATTTCTGTCGTGGTAGATGGAAGGTTTGTAAGTTAGTGTAAACAAAGAATATGCG CGACGCGTCGCACTTAAAATGTGTGTTACTTTTTTGATTTCATGTCACTCATCGTTTCTTTATTCTGTCTAAAGATTCGTATCTATGAAGTTTCTGGGGCAATACATTAACAAAGAAACT TTCT TTGTTATTGTAAGTTATAAATGTTGACTAGTCCAACCACACTACT TAACA ATTACCAACAGCTTTTCAACAGTTTTGGAAGGGCAATTGAGAAATTGCT AGAGACGGTTTTGAAGG ACGCTTTTGCAATTCCCTCAAGGCATCTT TGCT TGGCAATATT TGAAGCATCATTTTTTTATTGAATAACCATTGTGGGCCTTTAATCTCAATTGCGAAGATACATTTGTCTGGTTTTTT GAAATTCT TCCCT TTTACGA TTTTTGTATATTTTCTATTTCTTTTGTTATTCCTATATTT TATAAGCT TGCAACCTAATATTTGTATTATTGT TGCT AGCGCCTGTTTTTGAAGTGCTGC

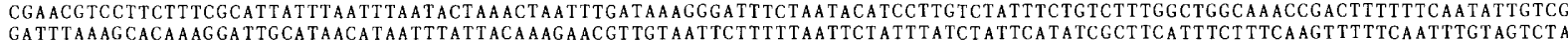

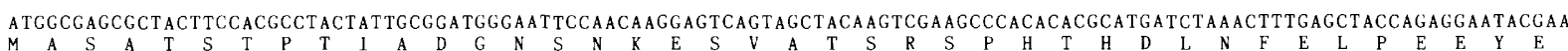

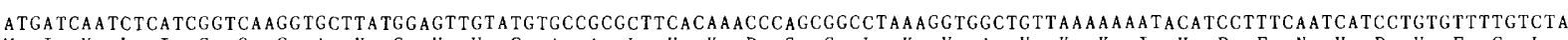
M I N N L

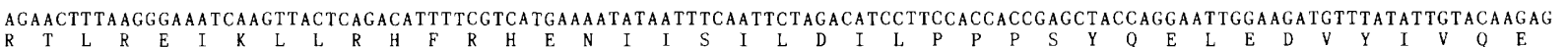

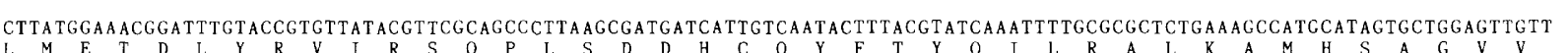

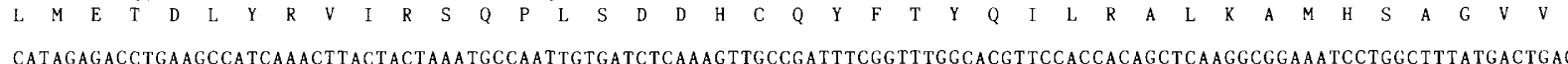

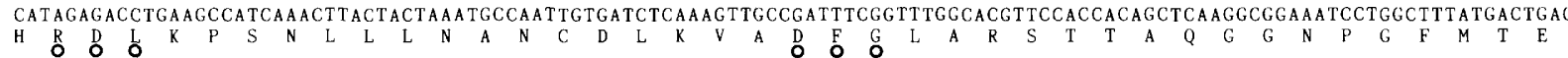

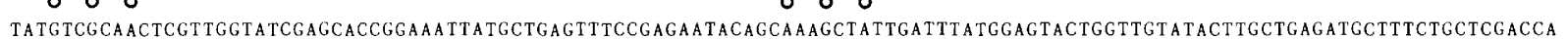
Y V V A A T

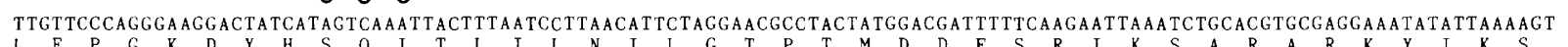

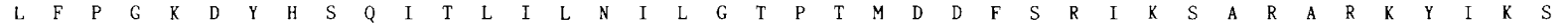

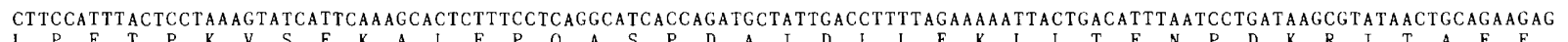
$\begin{array}{llllllllllllllllllllllllllllllllllllllll}\mathrm{L} & \mathrm{P} & \mathrm{F} & \mathrm{T} & \mathrm{P} & \mathrm{K} & \mathrm{V} & \mathrm{S} & \mathrm{F} & \mathrm{K} & \mathrm{A} & \mathrm{L} & \mathrm{F} & \mathrm{P} & \mathrm{Q} & \mathrm{A} & \mathrm{S} & \mathrm{P} & \mathrm{D} & \mathrm{A} & \mathrm{I} & \mathrm{D} & \mathrm{L} & \mathrm{L} & \mathrm{E} & \mathrm{K} & \mathrm{L} & \mathrm{L} & \mathrm{T} & \mathrm{F} & \mathrm{N} & \mathrm{P} & \mathrm{D} & \mathrm{K} & \mathrm{R} & \mathrm{I} & \mathrm{T} & \mathrm{A} & \mathrm{E} & \mathrm{E}\end{array}$ GCTCTAAAGCACCCGTATGTAGCTGCTTATCATGATGCCAGTGATGAGCCTACAGCATCCCCCATGCCTCCCAACCTCGTCGATTTATACTGTAACAAAGAaGATCTCGAaATACCGGTA

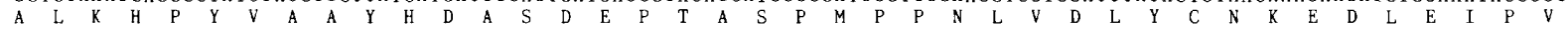

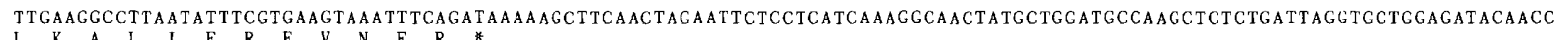

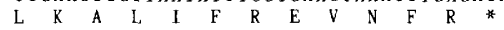

TGTCGGTTGAGTTCCAGCTTCTTTAGATAACTCAGT AGTAGGTCATG TGCGACTATCAATGTGTTTAATAAAGAGCAAATGGATGTCGGACTGAATGCGACAATCCAATCAATTGT AGGA TGT TTTCT AATCGT ATCCT T TATTTGGGT TTCTGTATTTTCT AATTCT TGCGT AGATATACGATTAATGAATCTACTCTGTCGTCCCCCAGT TTTCT T TGAATTATATCCCT ATGCT TT T CCCCTACAAGGAAAAGTAAGGGCTTATGTTGTTTAGTCGTAGTAT ACCACTCTTCAATTAAATCTGCCAAAACCTCACCCCTCCCACAGTCCTTTCCATGTGT TTGCTG AAAACCGAGAC GTCGAATACT ATCA TCAGTCGCCGGACCT ACTGTAAATATTGGTG TCTCCATCAATATTTTCCTGCCTCTCCGTTTCATCT TCT TG TTT TAATGCTTCA TCCAGAGTTTCGCTAACTCGT TGACTGGTAACGATTAAACCACAATAAGTTTTACGAACGTTTTTTAATTTATCTCTAAGCTGTTCTTCGTGAACCCTTTTGTGTCTCAGCACAGGAATGAAGGC TGTATCTCTTCCATAT TT TTCAAAG GCCTCCACATATGGATCGAAAGGTGTGATT TGGTTTTCA AT AGCAAAGCAGT TT TCATGCT TTGTCT TT ACA ATT TGAGA AATGT AAAAAAATAATT ACAGTGTCATCT A GTTCCTCAACCTATTCTACGCTTATTCTGACCAGTGAGCAGTAGCACAATTTGGCAGATGGAACAAACATGCATCTTTCCACATCGCTAATCAAATCATT AACT TAACTCAAATTCGTA AAAAATAAATACCGTCATCGGT TGACAAATTTTTTAAAAAATGAATGCTTCTGGAAAAACGGTAAACGATAGTTTAAAAGTATCTGATC

1691

1680

1560

1440

$-1320$

$-1200$

-1080
-960

$-840$

$-720$

$-600$

$-480$

$-360$

$-240$

$-120$

+1
40

$+121$

80

+241
120

$+361$

160

$+481$

200

+601
240

$+721$

280

+841
320

$+961$

360

1081
372

$+1201$

$+1321$

+1441
+1561

$+1561$

$+1681$

$+1921$

$+2041$

(99)

(74)

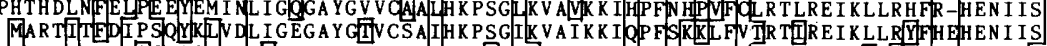

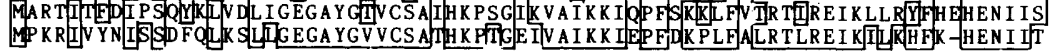

VI

VII

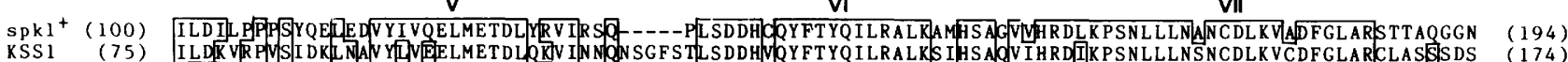

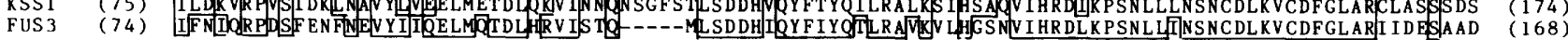

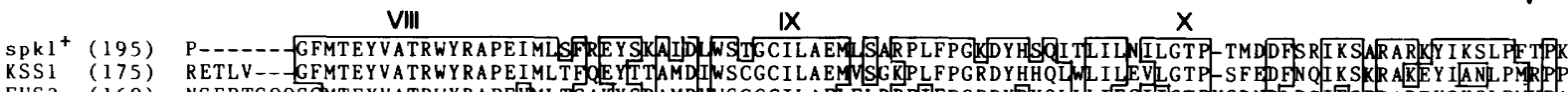

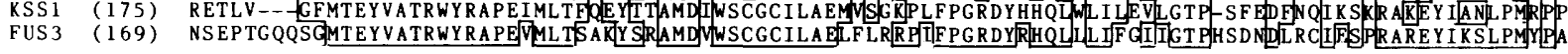

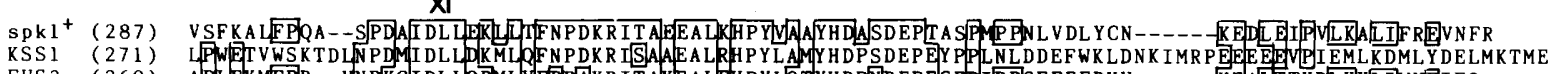

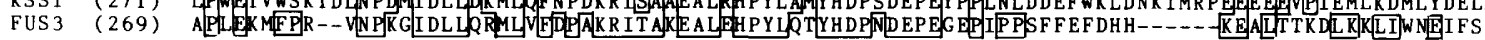

Figure 2. (See following page for legend.) 
Figure 3. Identification and characterization of the $s p k 1^{+}$gene product. (A) Cell extract prepared from wild-type $S$. pombe cells (HM123, Table 2) transformed with the vector $\mathrm{pDB} 248$ (lanes $1-3$ ) or with the multicopy plasmid containing the $s p k 1^{+}$ gene connected with the ADH promoter (lanes 4-6) were immunoprecipitated with preimmune serum (lanes 1 and 4 ) diluted anti-spk1 serum (lanes 2 and 5), or enriched affinity-purified anti-spkl antibody (lanes 3 and 6). Immune complexes were run in $10 \%$ SDS-PAGE, transferred to nitrocellulose, and immunoblotted with affinity-purified anti-spkl antibodies and ${ }^{125}$ I-labeled protein $A$. The faint bands at $50-60 \mathrm{kD}$ that appear in all of the lanes correspond to IgG used for im-
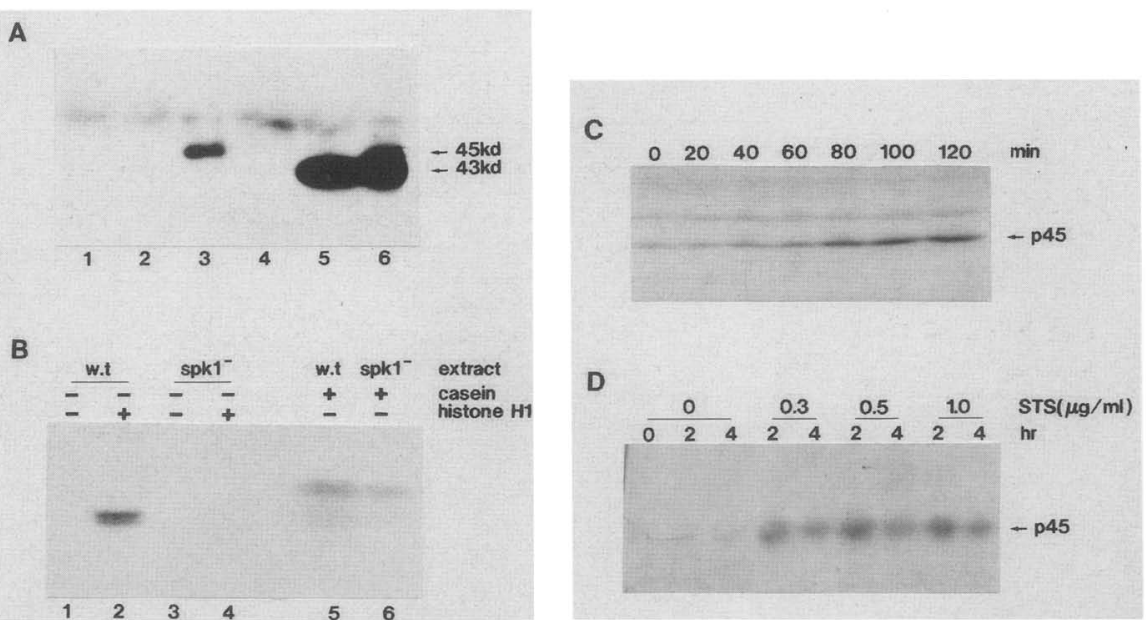
munoprecipitation. $(B)$ An in vitro protein kinase reaction was carried out using histone $\mathrm{Hl}$ as an exogenous substrate. Immune complexes using affinity-purified anti-spkl antibodies were prepared from wild-type (HM123; lanes 1,2, and 5) or spk1- (TP106-3C, see Table 2) cell extracts (lanes 3, 4, and 6). Immunoprecipitates were incubated with $\left[\gamma^{-32} \mathrm{P} \mid \mathrm{ATP}\right.$ in the absence (lanes 1 and 3) or presence of either histone H1 (lanes 2 and 4 ) or casein (lanes 5 and 6). Reaction mixtures were run on 15\% SDS-PAGE, followed by autoradiography of the dried gel overnight at room temperature. $(C)$ Time course of induction of the $s p k 1^{+}$protein by addition of staurosporine is shown. Staurosporine $(0.5 \mu \mathrm{g} / \mathrm{ml})$ was added to exponentially grown $S$. pombe cells, and cell extracts were prepared at 20 -min intervals. Each extract preparation was run on 12.5\% SDS-PAGE and immunoblotted with anti-spkl antibodies, followed by visualization using a peroxidase-immunostaining kit (Konica). (D) Increase in the amount of the $s p k 1^{+}$protein in various concentrations of staurosporine is indicated. Extracts were prepared before and 2 or $4 \mathrm{hr}$ after drug addition. The drug (denoted by STS) concentrations added are $0,0.3,0.5$, and $1 \mu \mathrm{g} / \mathrm{ml}$, respectively. Samples are immunoblotted as in $C$, except that $7.5 \%$ SDS-PAGE was used. This difference causes the p45 bands to appear broader than those in $C$.

growth rate of these cells was significantly slower than that of wild type; the average generation time of pap1cells is $175 \mathrm{~min}$ at $33^{\circ} \mathrm{C}$ in a rich liquid YPD, whereas that of wild-type is $130 \mathrm{~min}$. The nonessential standing of pap $1^{+}$may be caused by the functional redundancy of the AP-1-binding factors. Recently, we have detected a weak but reproducible AP-1-binding activity in extracts prepared from the pap1- cells (T. Toda et al., unpubl.).

We found that pap1- cells were hypersensitive to staurosporine. As shown in Figure 7A, pap1- null mutants did not form colonies on plates containing 0.2 $\mu \mathrm{g} / \mathrm{ml}$ of staurosporine, and drug supersensitivity and uracil prototrophy cosegregated in tetrads. We then examined whether multicopy $s p k 1^{+}$gene could confer staurosporine resistance in a pap1- background. One set of tetrad segregants was transformed with multicopy plasmids containing either vector sequence alone or pap $1^{+}$or $s p k 1^{+}$gene-containing plasmids (Fig. 7B, lanes 1,2 , or 3 , respectively), and the drug sensitivity of each transformant was determined. It was evident that pap1cells carrying the $s p k 1^{+}$kinase gene on multicopy plasmids were still sensitive to the drug (right panel, lane 3; cf. a, d and b, c), although the same cells containing high-dose pap $1^{+}$could grow on plates containing $0.3 \mu \mathrm{g} / \mathrm{ml}$ staurosporine (lane 2). These results indicate that the pap $^{+}$gene is required for $\operatorname{spk} 1^{+}$to confer staurosporine resistance (for a summary of drug resistance of each transformant, see Table 1). On the other hand, when carried on multicopy plasmids, the pap $1^{+}$ gene could confer drug resistance to spk1- cells (Table 1).

\section{Discussion}

In this study we report that staurosporine, an in vitro inhibitor of PKC, blocks growth of S. pombe cells specifically at a stage immediately after cell division, and we

Figure 2. Cloning and sequencing of the $s p k 1^{+}$gene and its homology to the budding yeast KSS1 and FUS3 genes. (A) Restriction map and subcloning results of plasmid pST23 are shown: $1+$ Complementation of drug sensitivity (Table 1); the wavy line indicates the vector sequence; the hatched box represents the predicted ORF. The direction of transcription is from left to right. (J) A junction between the insert S. pombe DNA and the vector sequence. $(\mathrm{Bc})$ BclI; $(\mathrm{Bg}) \mathrm{BglII} ;(\mathrm{Bm}) \mathrm{BamHI} ; \mathrm{R})$ EcoRI; $(\mathrm{H}) \mathrm{HindIII}$; $(\mathrm{Sc}) \mathrm{SacI} ;(\mathrm{Sl}) \mathrm{SalI}$. Only the BamHI and BgIII restriction sites in the insert have been mapped completely. $(B)$ The 3821 nucleotides of the SaII fragment (see $A$ ) are shown together with the predicted amino acid sequences. A single-letter code is used to assign the amino acid residues. (O) The consensus sequence for an ATP-binding site (see text); (O) invariant sequences among known protein kinases (Hanks et al. 1988). The $3^{\prime}$-termination codon is indicated by the asterisk $(*)$. It should be noted that the amino acid sequence at the extreme amino terminus is tentative. The $1.2-\mathrm{kb}$ HindIII fragment that supposedly contains all of the coding sequence connected with the ADH promoter did not confer drug resistance. Furthermore, the molecular mass $(43 \mathrm{kD})$ of the protein produced from that sequence was shown to be $\sim 2 \mathrm{kD}$ smaller than that of the intact $s p k 1^{+}$protein $(45 \mathrm{kD})$ by immunoblot of SDS-PAGE (Fig. 3A, see text). Thus, an unidentified intron may exist in the $5^{\prime}$-flanking region. $(C)$ Homology among the amino acid sequences of spk $1^{+}$, the budding yeast KSS1 (Courchesne et al. 1989), and FUS3 (Elion et al. 1990) gene products. Identical amino acids are marked by open boxes. The Roman numerals above the sequence refer to conserved subdomains found in all protein kinases (Hanks et al. 1988). 


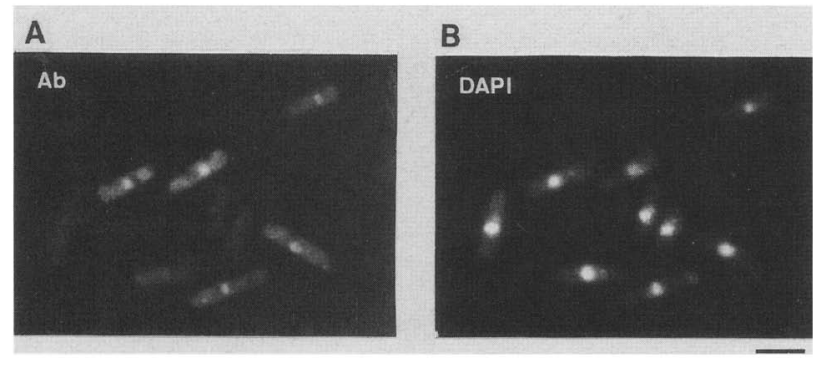

Figure 4. Cellular localization of the $s p k 1^{+}$protein. Immunofluorescence microscopy of $S$. pombe cells that overproduce the $s p k 1^{+}$protein is shown. Cells were stained with affinity-purified anti-spkl antibody, followed by rhodamine-conjugated second antibody $(A$, denoted by $\mathrm{Ab})$ and the DNA-binding fluorescent dye, DAPI $(B)$. Bar, $10 \mu \mathrm{m}$.

describe the isolation and characterization of the two fission yeast genes that confer resistance to staurosporine when carried on multicopy plasmids. One gene, $s p k 1^{+}$, encodes a novel $45-\mathrm{kD}$ protein kinase enriched in the nucleus and resembling the mammalian ERK1/ MAP2 kinase and budding yeast KSS1 and FUS3, and the other gene, $p a p 1^{+}$for an $S$. pombe AP-1-like factor.

The stage blocked by staurosporine is of particular interest in terms of growth control of fission yeast as cells enter the phase of cell elongation at this time. At first, tip growth occurs asymmetrically only at the old end of cells, which existed in the previous cycle (Streiblova and Wolf 1972). This early stage of cell elongation and not those after the stage referred to as NETO (new end takeoff; Mitchison and Nurse 1985), when the new end of the cell starts to grow, appears to be staurosporine sensitive. It should be noted that in the rich medium used in this study, $S$. pombe apparently lacks a $\mathrm{G}_{1}$ phase; cells immediately start to replicate DNA upon completion of nuclear division. Thus, our analysis does not rule out the possibility that staurosporine might affect $G_{1}$ cells. When higher drug concentrations $(>10 \mu \mathrm{g} / \mathrm{ml})$ were used, the block of cell growth was no longer cell-cyclestage specific; cells arrested immediately after the addition of the drug. Hence, the target molecules most sensitive to staurosporine should be responsible for the early stage of cell growth. Although in vitro studies (Tamaoki et al. 1986; Nakano et al. 1987) indicated that PKC was the most staurosporine sensitive of the kinases examined, the situation might be quite different in vivo, and other kinases may well be targets of the drug.

Although much is now known about the regulation of late $\mathrm{G}_{2}, \mathrm{G}_{2} / \mathrm{M}$ transition from the study of $c d c 2^{+}$, suc1 ${ }^{+}$, and $c d c 13^{+}$as components of MPF (Booher et al. 1989; Moreno et al. 1989|, regulation of the entry into the increase of cell mass in fission yeast is scarcely understood. Genes identified by staurosporine-hypersensitive mutations or high-dose resistance might provide the clue to understanding this process. So far, we have isolated 4 genes that confer resistance by high gene dose and identified 11 sts genes that determine hypersensitivity. Two of the four former genes are reported in this paper, but the products of the remaining genes have not been identified except for $s t s 1^{+}$, which contains membrane-spanning domains (T. Toda and M. Shimanuki, unpubl.). The $s t s 1^{+}$gene is required for the conferring of high gene dose resistance by $s p k 1^{+}$and $p a p 1^{+}$; multicopy plasmids containing either $p a p 1^{+}$or $s p k 1^{+}$cannot confer staurosporine resistance in the sts 1 mutant background. The genetic and biochemical interrelationships between the resistance-conferring and hypersensitive genes have not been investigated. Mutants strongly resistant to staurosporine have not been isolated, probably because the number of the targets would increase under higher drug concentrations. The existence of PKC-like genes has been reported recently in budding yeast (Levin et al. 1990; Ogita et al. 1990). It is not known whether yeast PKC is highly sensitive to staurosporine. PKC might be an in vivo target for staurosporine if it exists in fission yeast, and it remains to be seen whether any of the $s t s^{+}$and high-dose resistance genes encodes a PKCrelated protein.

An intriguing question is whether $s p k 1^{+}$is a direct cellular target for the drug. We found that the spk1+ protein is induced up to 10 -fold by the addition of staurosporine. This may represent a close relationship between the drug and the expression of $s p k 1^{+}$gene. In some cases, such as those between hydroxyurea and ribonucleotide reductase (Elledge and Davis 1987) and between compactin and HMG-CoA reductase (Brown and Goldstein 1980), inhibitors are known to induce synthesis of the target enzymes. It should be noted, however, that an spk1 null strain is viable and has a staurosporine sensitivity indistinguishable from that of wild type. Therefore, it is equally possible that $s p k 1^{+}$is only indirectly related to the drug. The amount or susceptibility of other kinase(s) as the primary staurosporine target(s) may be regulated by the $s p k 1^{+}$gene. This hypothesis is consistent with the nuclear localization of spk $1^{+}$protein.

The amino acid sequence of $s p k 1^{+}$is highly homologous to the recently reported $S$. cerevisiae KSS1 and FUS3 proteins and mammalian ERK1/MAP2 kinase. The growth-regulated properties of ERK1/MAP2 kinase have been well documented; mitogens and growth factors rapidly activate the MAP2 kinase (Boulton et al. 1990). High-dose KSS1 in budding yeast promotes recovery from pheromone-induced growth arrest in $G_{1}$ phase. The KSS1 protein acts positively on the mitotic cell cycle (Courchesne et al. 1989). The FUS3 protein, however, works antagonistically to KSS1; FUS3 is required for both $\mathrm{G}_{1}$ arrest and conjugation (Elion et al. 1990). Both KSS1 and FUS3 are involved in growth control of budding yeast. Although the disruption phenotypes of $s p k 1^{+}$and FUS3 are essentially the same (viable and conjugation defective), it remains to be determined whether spk $1^{+}$and FUS3 are interchangeable.

High-dose pap $1^{+}$confers staurosporine resistance, and we have shown that the $p a p 1^{+}$gene product behaves as an AP-1-like transcription factor. A comparison between pap $1^{+}$and budding yeast YAP1 indicates an extremely high degree of homology in the basic region adjacent to the leucine repeats; 11 continuous amino acid residues 


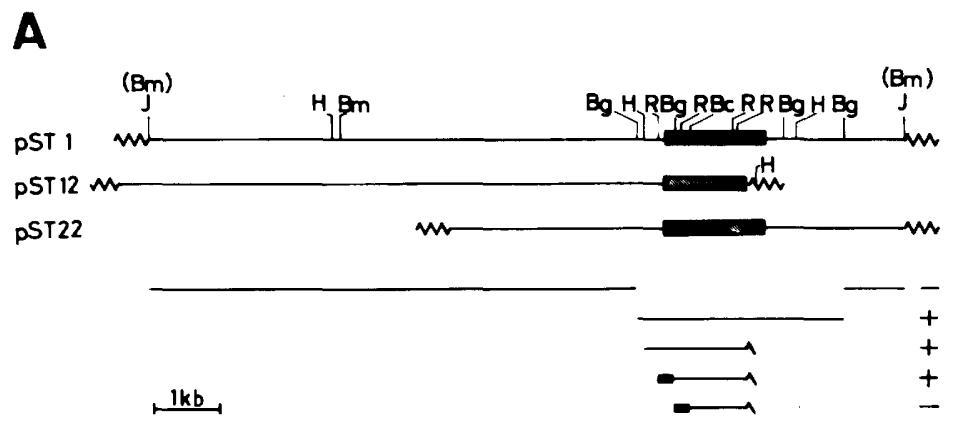

B

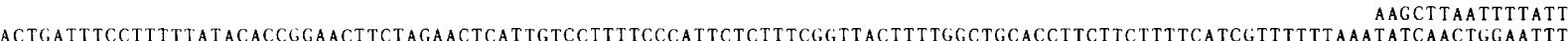

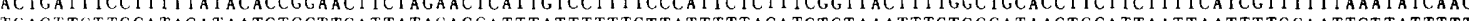
ATCTTGCATGCTT TGTGAATTACATTCTTTTT TACAGAGCTCTTATTT ATAAATTTTTTATCCTATCGATACTACATTT TTCAAAGGAGCATACATTCGTGTTAATTAATGATAATT

ATCTCCGGACAAACTGAGACGT TGTCATCTACT TCAAACATTCCAAT TGCAAAGCGGaACCAGAGCAATCCGCCGATT TT TCAGCTTCACATAAaAaACCTGGTCCCGTTAGTGaCAGA

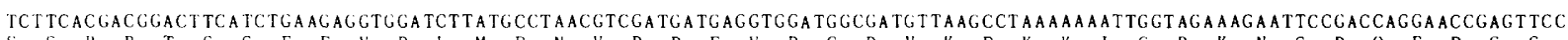

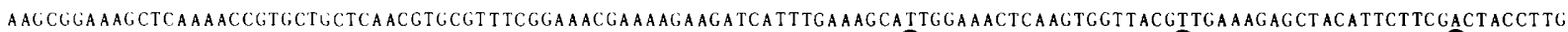

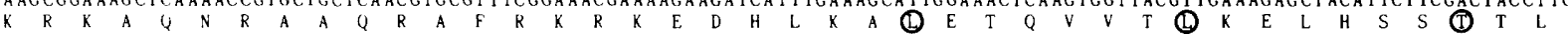

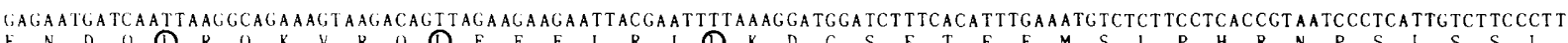

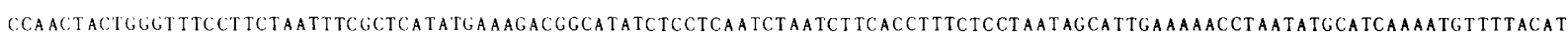

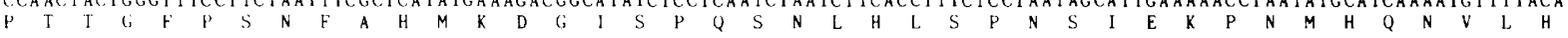

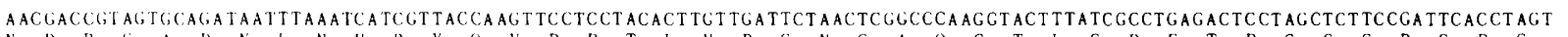

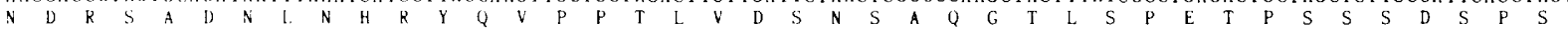

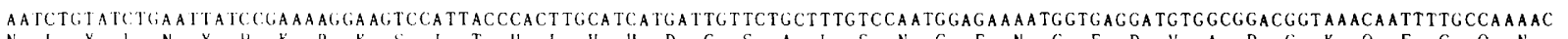
N L L Y

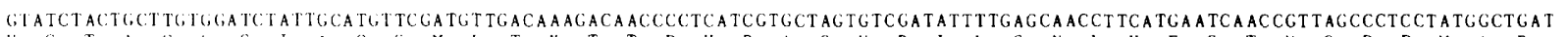

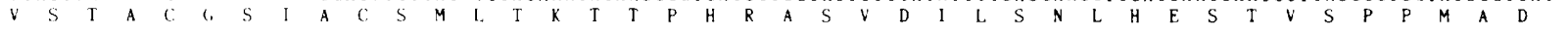

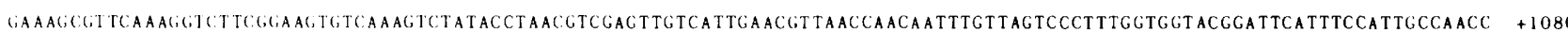

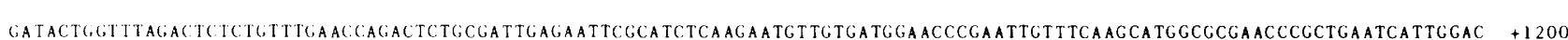
D T G G L L D S L L F F E F

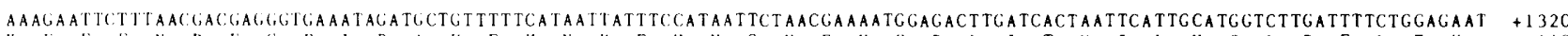
$\mathrm{K} E \mathrm{E} / \mathrm{F}$ N D F

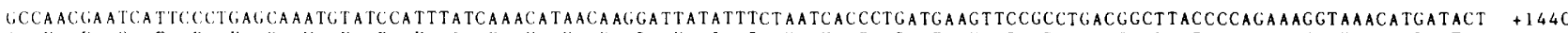

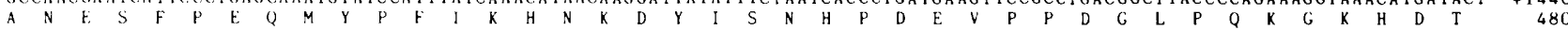

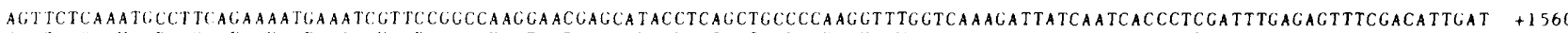
$S$ S Q M M P

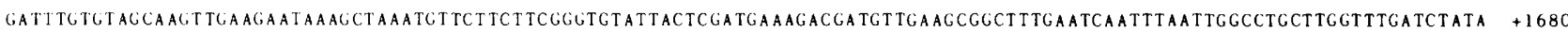
D L C S S K L K K N K A K C S S S G V L L D E R R C *

TCGATGTTATAACGACTTTTTGCITATTTTTATATGTATTTCCATTGTTTTAATTAATAGTACCTTTTTGTTTTTCTTCGCCTCGTGaTATAATCAACGCATATTTTCAATACCGATTAG +1800 AAAAGTAAGGAATGATAA TGACTTTTAGTTTAGTGTGTAAAACAATTCATTTCTATTTTTTGAAGATCTATATTTTTATTATAATTTACTTTTTTTTTGAACTTGTTATGTGCGAGATGA +1920

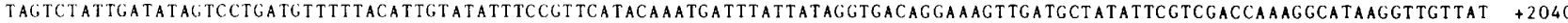
TTGACATTTCTTTGTATTC.TATTATATCTTAAACAGaTGTGTATTTTAATACAGTATAAATTAAGTGTACAGTAGTAGTTACGAATCAACACCAAACAGACATTGTGTGCTTAaACTTCA +2160 AGCT T

C

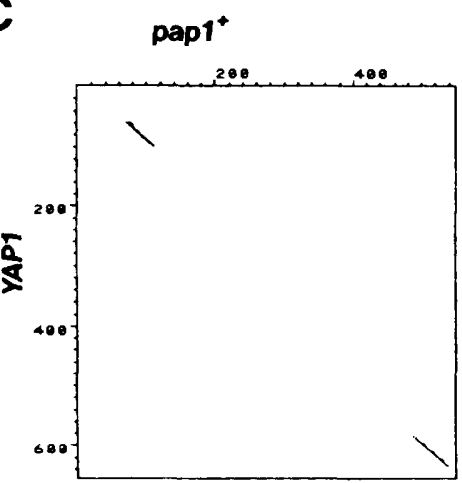

D

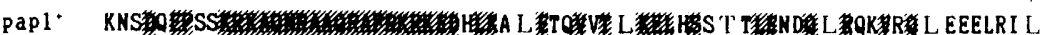

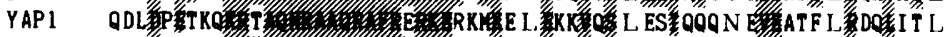

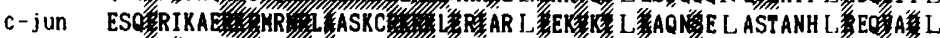

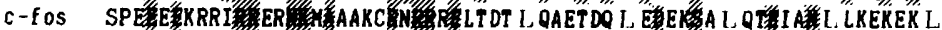

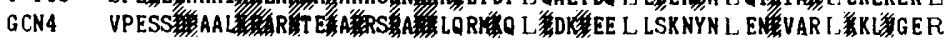

E

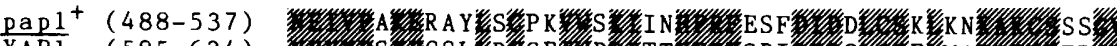

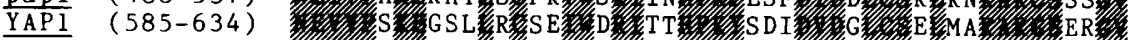

Figure 5. (See facing page for legend.) 
in the basic region are identical. This region is believed to determine a sequence-specific DNA-binding activity of the c-jun/c-fos proteins (Kouzarides and Ziff 1988; Gentz et al. 1989; Turner and Tjian 1989; Vinson et al. 1989). A high degree of homology between pap $1^{+}$and YAP1 in this region may reflect similar target sequences.

One question raised is that of how overproduction of the transcription factor $p a p 1^{+}$confers staurosporine resistance. A simple explanation is that the pap $1^{+}$protein is one of the cellular targets for the drug. This is unlikely, because there is no indication for a direct interaction between bacterially produced pap $1^{+}$protein and the drug; pap1 $1^{+}$normally binds to the AP-1 site in the presence of an excess concentration of the drug (data not shown). The second possibility is that the pap1+ protein, in some way, activates target protein kinases, and as a result cells containing multicopy pap $1^{+}$plasmids become more resistant to the drug. Alternatively, there may be a feedback mechanism such that inactivation of a target protein kinase causes the activation of its transcription factor. These hypotheses are consistent with the drug hypersensitivity of a pap1- null mutant that is perhaps unable to increase the level of target protein kinases.

The evidence suggests that the $s p k 1^{+}$protein kinase and pap $1^{+}$are functionally interrelated, although the link between them may not be direct. We showed that multicopy $s p k 1^{+}$genes could not confer drug resistance in the absence of the pap1 $1^{+}$gene. On the other hand, multicopy pap $1^{+}$plasmids could increase drug resistance in $s p k 1^{-}$cells. High-dose pap $1^{+}$, however, could not complement the other spk1- phenotypes; spk1cells containing multicopy pap $1^{+}$plasmids are still conjugation defective. A plausible hypothesis to explain our result is that a major target protein kinase of staurosporine, which is directly linked with pap1 ${ }^{+}$, is yet to be identified. Conferring drug resistance may require a certain level of that major target kinase; both $s p k 1^{+}$and pap $1^{+}$genes regulate the amount of activity of the target kinase in different ways.

\section{Materials and methods}

Strains, media, and chemicals

$S$. pombe strains used in this study are listed in Table 2. Rich YPD (1\% yeast extract, $2 \%$ polypeptone, 2\% dextrose), minimal SD $10.67 \%$ yeast nitrogen base without amino acids, $1 \%$ dextrose), and SPA media (Gutz et al. 1974) were used. Plates contained $1.6 \%$ of agar. Staurosporine $(2 \mathrm{mg} / \mathrm{ml}$ was provided by Dr. H. Nakano, Kyowa Hakko Co.) was dissolved in dimethylsulfoxide (DMSO), and stock solutions of $0.5 \mathrm{ml}$ each were stored at $-20^{\circ} \mathrm{C}$. The stock solution was diluted 10-fold with ethanol just before use.

\section{Genetic techniques and nomenclature}

Standard procedures for $S$. pombe were followed according to Mitchison (1970, 1988) and Gutz et al. (1974). Gene disruptions are denoted by lowercase letters representing the disrupted gene followed by two colons and the wild-type gene marker used for disruption. In this paper gene disruptions are abbreviated by lowercase letters representing the gene, followed by a superscript minus sign, such as pap1-.

\section{Isolation and characterization of the staurosporine- supersensitive mutants}

Wild-type HM123 (Table 2) cells were mutagenized with $N$ methyl- $N^{\prime}$-nitro- $N$-nitrosoguanidine as described previously (Uemura and Yanagida 1984). Supersensitive mutants (called ss) that could not grow on YPD plates containing $0.2 \mu \mathrm{g} / \mathrm{ml}$ of staurosporine were isolated by replica plating. Approximately 200,000 colonies were screened, and 18 independent mutant strains were obtained (ss1-ss18). Backcrossing with a mater strain (JY6; Table 2) indicated that ss phenotypes of all the strains but two (ss1 and ss11) were due to a single chromosomal mutation. Each of the two strains, ss1 and ss11, contained double mutations, either of which alone showed a ss phenotype. Complementation test was done by crisscrossing each of the mutant strains. Segregants were examined for drug sensitivity, and 11 genetic loci (called sts1-11) were identified. Dominant-recessive tests were done by constructing prototrophic diploids between individual mutants and a meiosis-deficient mater strain (JY183; Table 2).

\section{Cloning of genes that can suppress drug sensitivity}

$h^{-}$leu1 strains of sts1-5, sts2-6, and sts3-15 (Table 2) were transformed with an $S$. pombe genomic library constructed in pDB248 (Beach and Nurse 1981, Beach et al. 1982, Hirano et al. 1988) using the lithium method (Ito et al. 1983). These alleles were chosen because their transformation efficiencies were the best. $\mathrm{Leu}^{+}$transformants were replica-plated on YPD containing $0.2 \mu \mathrm{g} / \mathrm{ml}$ of staurosporine. Those that could grow on drug- containing plates were picked up, and their segregation pattern was analyzed. Plasmid DNAs were recovered as described (Nasmyth and Reed 1980). We obtained one sts1 ${ }^{+}$-containing plasmid from $s t s 1-5$, one $s t s 2^{+}$-containing plasmid from sts2-6, one $s p k 1^{+}$-containing plasmid (Fig. 2A), and three different pap1 $1^{+}$-containing plasmids (Fig. 5A) from sts3-15.

Figure 5. Cloning, sequencing, and amino acid sequence homology of $p a p 1^{+}$. (A) Subcloning analysis of three overlapping plasmids (pST1, pST12, and pST22). The direction of transcription in the pap1 $1^{+}$gene is from left to right. The small solid box indicates the $\mathrm{ADH}$ promoter. The designation of restriction enzymes is the same as in Fig. 2. (B) The 2540-nucleotide sequence of the HindIII fragment (see $A$ ) is shown along with the deduced amino acid sequence. The heptad leucine repeats are shown $(O)$. $(C)$ Homology matrix of a comparison between the pap $1^{+}$protein (ordinate) and the YAP1 protein (abscissa) amino acid sequence is shown. The window for homology is $>10$ identical residues in 30 contiguous amino acids. Two regions of homology are found (see text). $(D)$ Identical and conservative amino acids between pap $1^{+}$and $j u n / f o s-r e l a t e d$ proteins are marked with hatched boxes. The residues corresponding to the basic region and the leucine repeats are shown. The arrows represent the positions of heptad leucines (shown by larger letters). Note that the amino acid in the third position of the repeats in pap $1^{+}$and YAP1 are threonine and asparagine, respectively. References for the amino acid sequences for YAP1, c-jun, c-fos, and GCN4 are Moye-Rowley et al. (1989), Bohmann et al. (1987), van Straaten et al. (1983), and Vogt et al. (1987), respectively. (E) The carboxyl 50-amino acid sequences of the pap1 ${ }^{+}$and YAP1. Identical and conservative amino acid residues are hatched. 


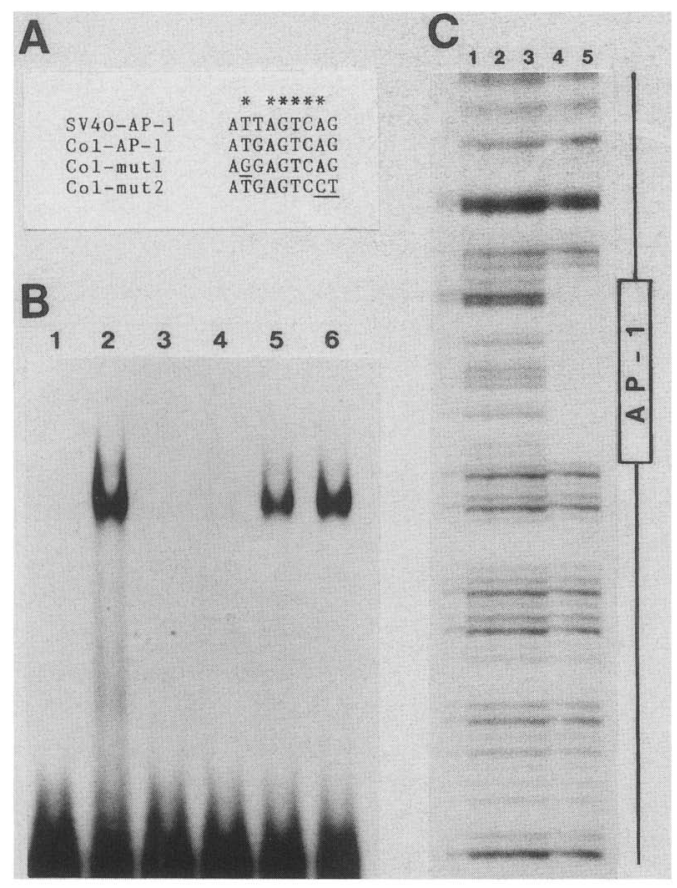

Figure 6. DNA-binding specificity of the pap $1^{+}$protein. $(A)$ The AP-1-binding core sequences of the synthetic oligonucleotides used here are shown (Jones et al. 1988). SV-AP-1 contains the AP-1-binding site of the SV40 early promoter/enhancer region and Col-AP-1 contains that of the human collagenase gene. Col-mutl and Col-mut 2 are the two mutated forms of the collagenase AP-1 site. Underlined nucleotides indicate the replaced nucleotides. The asterisks (*) indicate those nucleotides essential for AP-1 binding (Angel et al. 1987). (B) Gel retardation analysis was performed according to Fried and Crothers (1981), using the end-labeled Col-AP-1 as the probe. Labeled probes ( $1 \mathrm{ng}, 3 \times 10^{4} \mathrm{cpm}$ ) were incubated with $0.25 \mu \mathrm{g}$ of purified T7-papl ${ }^{+}$protein made in E. coli (lanes 2-6). No protein was added in lane 1 . Each lane contained $2 \mu \mathrm{g}$ of poly[d(I-C)] as the carrier. Specific competitor oligonucleotides used were as follows: SV-AP-1 (lane 3), Col-AP-1 (lane 4), Col-mut1 (lane 5), and Col-mut2 (lane 6). The amount of each competitor added was to a 400-molar excess. (C) DNase I footprint analysis of the SV40 early promoter/enhancer region using sequences end-labeled in the noncoding strand as the probe. The amounts of the T7-pap $1^{+}$protein used were $0 \mathrm{ng}$ (lane 1), $25 \mathrm{ng}$ (lane 2), $50 \mathrm{ng}$ (lane 3) $100 \mathrm{ng}$ (lane 4), and $250 \mathrm{ng}$ (lane 5) in a $50-\mu 1$ reaction volume.

\section{DNA preparation and manipulation}

Plasmid DNA was isolated from E. coli using the alkali-lysis method (Maniatis et al. 1982). Yeast DNA was prepared as described (Nasmyth and Reed 1980). Standard molecular cloning techniques were followed as described (Maniatis et al. 1982). Enzymes were used as recommended by their suppliers (Takara Shuzo Co., Toyobo Co., Worthington, or Bethesda Research Labs.)

\section{Nucleotide sequence determination}

The dideoxy method (Sanger et al. 1977) was used in combination with the unidirectional progressive deletion method (Henikoff 1984) using double-stranded plasmid DNA as template
(Hattori and Sakaki 1986). Nucleotide sequence of the $s p k 1^{+}$ gene was determined as follows. Subcloning analysis of pST23 suggested that either site of the $5.0-\mathrm{kb}$ BgIII must be located inside the coding region (see Fig. 2A). Nucleotide sequence was determined from both sides of the BglII fragment. One of the two sides (a rightward end side in Fig. 2A) was shown to be in the middle of an ORF, and computer search using NBRF revealed that amino acid sequences of that ORF have a significant homology to those of various known protein kinases. The 4.0kb Sall fragment of pST23 was subcloned into Bluescript (Stratagene, designated as pRS4.0S), and an entire sequence was determined. For sequencing the pap $1^{+}$gene, $2.5-$ and $2.0-\mathrm{kb}$ HindIII fragments of pST1 and pST12 (Fig. 2A) were subcloned into pUC18 (Yanisch-Perron et al. 1985) and Bluescript (designated pPA2.5H and pPA2.0H, respectively). More than $80 \%$ of the coding regions of both the genes were sequenced; and in regions where only one direction was read, nucleotide sequence was confirmed by sequencing at least two different template plasmid DNAs.

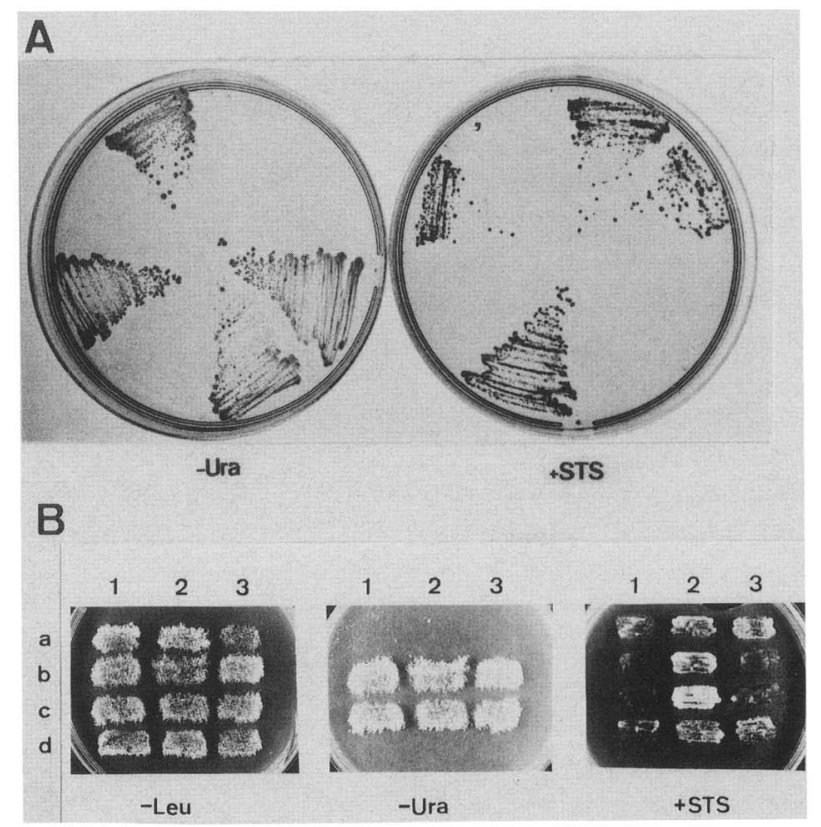

Figure 7. Phenotypes of the pap1+ gene disruptant. (A) Two sets of tetrad segregants were streaked on a minimal plate lacking uracil (-Ura; left) and a YPD plate containing 0.2 $\mu \mathrm{g} / \mathrm{ml}$ of staurosporine ( $+\mathrm{STS}$; right). Note that colony formation on the two plates exhibits a positive/negative correlation; $\mathrm{Ura}^{+}$cells grown in the left plate cannot grow on the drug-containing plate (right), while Ura- cells that cannot grow on the left plate can grow on the right plate. $(B)$ One set of tetrad segregants $(a-d)$ was transformed with three kinds of multicopy plasmids carrying only the vector sequence (lane 1), pap1+ (lane 2), or spk1+ (lane 3) genes, respectively. Transformants were streaked onto either minimal plates lacking leucine $(-\mathrm{Leu}$; left) or uracil (-Ura; middle), or a YPD plate containing 0.3 $\mu \mathrm{g} / \mathrm{ml}$ of staurosporine (+STS; right). Ura- segregants $(a$ and $d)$ can grow on the drug-containing plate if they contain multicopy plasmids carrying either pap $1^{+}$or $s p k 1^{+}$. On the other hand, Ura ${ }^{+}$segregants (pap1- null mutants, $b$ and $c$ ) are still staurosporine sensitive when transformed with $s p k 1^{+}$-containing plasmids (lane 3 , right), while they became drug resistant when transformed with plasmids carrying pap1+ (lane 2). 
Table 2. S. pombe strains used in this study

\begin{tabular}{|c|c|c|}
\hline Name & Genotype & Deviation \\
\hline HM123 & $h-1 e u 1$ & our stock \\
\hline JY6 & $h^{+}$leu1 his2 & our stock \\
\hline JY183 & meiI-B102 lys3 arg1 & our stock \\
\hline TP38-1A & $h-l e u 1$ sts $1-5$ & segregant of tetrads between ss 5 and JY 6 \\
\hline TP39-1C & $h^{-1}$ leu1 sts2-6 & segregant of tetrads between ss 6 and JY6 \\
\hline TP52-1B & $h^{-}$leu1 sts3-15 & segregant of tetrads between ss 15 and JY 6 \\
\hline TP4-1D & $h^{+}$leul his2 ura4 ade6-M216 & Ohkura et al. (1989) \\
\hline TP4-5A & $h^{-}$leu1 ura4 ade6-M210 & Ohkura et al. (1989) \\
\hline $5 \mathrm{~A} / 1 \mathrm{D}$ & $\begin{array}{l}h^{-/} / h^{+} \text {leu1/leu1 ura4/ura4 } \\
\quad+/ \text { his2 ade6-M210/ade6-M216 }\end{array}$ & Ohkura et al. (1989) \\
\hline TP20 & $\begin{array}{l}h^{-} / h^{+} \text {leu1/leu1 ura4/ura4 his2/+ } \\
\text { ade6-M210/ade6-M216 spk1 :: ura4 }{ }^{+/+}\end{array}$ & $\begin{array}{l}\text { a transformant of } 5 \mathrm{~A} / 1 \mathrm{D} \text { with } 2.6-\mathrm{kb} \\
\text { EcoRi fragment of } s p k 1:: \mathrm{ura}^{+}\end{array}$ \\
\hline TP21 & $\begin{array}{l}h^{-} / h^{+} \text {leu1/leu1 ura4/ura4 his2/ }+ \\
\text { ade6-M210/ade6-M216 pap1 :: ura4 } 4^{+} /+\end{array}$ & $\begin{array}{l}\text { a transformant of } 5 \mathrm{~A} / 1 \mathrm{D} \text { with } 2.8-\mathrm{kb} \\
\text { EcoRI fragment of pap } 1:: \mathrm{ura}^{+}\end{array}$ \\
\hline TP98-1A & $h^{-1 e u 1}$ ura4 sts $1-5$ & $\begin{array}{l}\text { segregant of tetrads between TP4-1D } \\
\text { and TP38-1A }\end{array}$ \\
\hline TP101-3A & $h^{+}$leu1 his2 ura4 ade6 & segregant of tetrads from TP21 \\
\hline TP101-3B & $h^{+}$leu1 his2 ura4 ade6 pap1 :: ura4 $4^{+}$ & \\
\hline TP101-3C & $h^{-}$leu1 ura4 ade6 pap1 :: ura4+ & \\
\hline TP101-3D & h-1eu1 ura4 ade6 & \\
\hline TP103-1A & $h^{+}$leu1 his2 ura4 ade6 spk1 :: ura4 ${ }^{+}$ & segregant of tetrads from TP20 \\
\hline TP106-3C & $h^{-1 e u 1}$ ura4 spk1 :: ura4 ${ }^{+}$ & $\begin{array}{l}\text { segregant of tetrads from diploids between } \\
\text { TP103-1A containing pST23 and TP98-1A }\end{array}$ \\
\hline TP108-3C & $h^{-1 e u 1}$ ura4 pap1 :: ura4 ${ }^{+}$ & $\begin{array}{l}\text { segregant of tetrads from diploids between } \\
\text { TP101-3B and TP98-1A }\end{array}$ \\
\hline
\end{tabular}

\section{Gene disruption}

For disruption of the $s p k 1^{+}$gene, the 1.2-kb EcoRI fragment containing most of the coding region (Fig. $2 \mathrm{~A}$ ) was subcloned into pUC18 (designated pRS1.2R). pRS1.2R (isolated from dam- GM33) was digested with BcII, and the $1.8-\mathrm{kb}$ BamHI fragment containing the $S$. pombe $\mathrm{ura}^{+}$gene (Grimm et al. 1988) was inserted. The $2.6-\mathrm{kb}$ fragment containing the

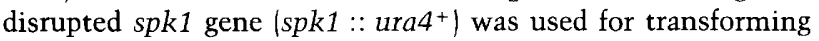
the homozygous ura4- diploids (Table 2). For disrupting the pap $1^{+}$gene, pPA2.0H (isolated from dam ${ }^{-}$GM33) was digested with BcII-BgIII, and a $1.8-\mathrm{kb}$ BamHI fragment containing the $S$. pombe $\mathrm{ura}^{+}$gene was inserted. The $2.8 \mathrm{~kb}$ EcoRI fragment containing disrupted pap1 was used for transformation of ura $4^{-}$ diploids. In each case, stable $\mathrm{Ura}^{+}$transformants were selected and disruption of the $\operatorname{spk} 1^{+}$or $p a p 1^{+}$gene was checked by genomic Southern hybridization.

Expression of the fused protein in $\mathrm{E}$. coli and preparation of antiserum

For construction of an expression plasmid for the fused protein of the spk1+ gene, the $1.0-\mathrm{kb}$ BamHI-BglII fragment from pRS1.2R was inserted into pET-3c (Rosenberg et al. 1987). This plasmid (pT7-spkl $1^{+}$was introduced into an E. coli strain $B L 21(D E 3)$ (Studier et al. 1986). Induced extract of the E. coli was fractionated according to Watt et al. (1985). SDS-PAGE was performed as described (Laemmli 1970). The fused protein (p43) that was insoluble was recovered from the gel (Hirano et al. 1988). For production of the fused protein of the pap $1^{+}$gene, 1.4 $\mathrm{kb}$ of the $B g I I I-B a m H I$ fragment from pPA2.0H was inserted in pET-3a (Rosenberg et al. 1987). This plasmid (pT7-pap1 ${ }^{+}$) was used for purification of the fused protein as described above. The soluble fused pap $1^{+}$protein (p59) was purified from the gel and used for DNA-binding assay. Rabbit antisera were prepared as described previously (Hirano et al. 1988).
Overexpression of the $\mathrm{spk} \mathrm{l}^{+}$and $\mathrm{pap} \mathrm{l}^{+}$proteins in $\mathrm{S}$. pombe cells

The $2 \mu$ DNA-based, ADH promoter-containing vector, pAS248, was constructed as follows: The $5.8-\mathrm{kb}$ HindIII/XhoI fragment that contains a part of $2 \mu$ DNA and the $S$. cerevisiae LEU2 gene was isolated from pDB248 (Beach and Nurse 1981) and was ligated with HindIII/XhoI-digested Bluescript, yielding pSK248. The 0.7-kb HindIII-SacI fragment that contains ADH promoter (Russell and Hall 1983) was inserted into the same site in the polylinker region of pSK248, yielding pAS248. The 1.2-kb Hin dIII fragment containing the $s p k 1^{+}$gene (Fig. 2A) was subcloned into the $S m a I$ site of pAS248, yielding pADH-spk1 ${ }^{+}$. For overexpression of the truncated pap $1^{+}$gene, the 1.4-kb BglII$B a m H I$ fragment from pPA2.0H was inserted into the BamHI site of pAS248, yielding pADH-papl ${ }^{+}$. These plasmids were used to transform $S$. pombe cells.

\section{Immunochemical assays}

Immune complexes were prepared essentially as described by Booher et al. (1989), except that cell extracts $\left(1 \times 10^{8}\right.$ cell equivalents) were mixed with $20 \mu l$ of a $1: 1$ slurry of protein A-Sepharose beads (Pharmacia) that had been bound with appropriate serum. Immunoblotting was carried out by electrophoretically transferring the proteins to nitrocellulose filter (Towbin et al. 1979). Protein A labeled with ${ }^{125}$ I (Amersham) or peroxidase-conjugated goat anti-rabbit IgG (Bio-Rad) and an immunostaining kit (Konica) was used to detect the bound first antibodies.

For an in vitro protein kinase reaction, procedures by Booher et al. (1989) were also followed with slight modifications. Histone $\mathrm{H} 1$ (Boehringer Mannheim) and casein was used at 0.5 and $2.5 \mathrm{mg} / \mathrm{ml}$, respectively; 100-fold more ATP (final $20 \mu \mathrm{M}$ ) was used in the reaction mixture. 


\section{Immunofluorescence microscopy}

The procedures described by Hagan and Hyams (1988) were basically followed. $S$. pombe cells were fixed in methanol at $-20^{\circ} \mathrm{C}$ for $8 \mathrm{~min}$.

\section{Assay for specific pap1 + binding to the AP-1 site}

A gel retardation assay was performed as described (Fried and Crothers 1981). Oligonucleotides synthesized were the same as in Jones et al. (1988). After the oligonucleotides were annealed (Hurst and Jones 1987), they were end-labeled with T4 polynucleotide kinase. Approximately $1 \mathrm{ng}\left(3 \times 10^{4} \mathrm{cpm}\right)$ of the labeled probe was used. Competitor DNA was added at a level of 400-fold molar excess. A DNase I footprinting experiment was carried out according to Lee et al. (1987), except that binding reaction was done in $10 \mathrm{mM}$ Tris- $\mathrm{HCl}(\mathrm{pH} 7.5), 50 \mathrm{mM} \mathrm{NaCl}, 1$ mM EDTA, 10\% glycerol, and $0.5 \mathrm{~mm}$ DTT. pW2/Bgl (provided by Dr. M. Imagawa; Zenke et al. 1986), which contains the SV40 enhancer region including two copies of 72 -bp repeats, was used for preparation of the probe fragment. pW2/Bgl was linearized with BamHI (at position -106) and labeled with $\left[\alpha^{-32} \mathrm{P}\right] \mathrm{dCTP}$ and RAV-2 reverse transcriptase. The $240-\mathrm{bp}$ fragment that contains the enhancer region was purified after the second digestion with EcoRI $(-106$ to -346$)$. In either assay, reaction mixture usually contained $2 \mu \mathrm{g}$ poly $[\mathrm{d}(\mathrm{I}-\mathrm{C})]$ (Pharmacia), unless otherwise stated. Binding reactions were incubated for $15 \mathrm{~min}$ at room temperature.

\section{Acknowledgments}

We are grateful to Dr. F. W. Studier for a T7 RNA polymerasedependent expression system, to Dr. M. Imagawa for plasmid pW2/Bgl, to Drs. P. Russell and D. Beach for an ADH promoter containing plasmid pART1, and Dr. H. Nakano for staurosporine. Special thanks are given to Dr. M. Goebl for pointing out homology between spk1+ and KSS1. We also thank Ms. F. Nishimura for her help in isolating mutants. This work was supported by grants from the Ministry of Education, Science, and Culture, and the Science and Technology Agency of Japan.

The publication costs of this article were defrayed in part by payment of page charges. This article must therefore be hereby marked "advertisement" in accordance with 18 USC section 1734 solely to indicate this fact.

\section{References}

Angel, P., E. Allegretto, S. Okino, K. Hattori, W.J. Boyle, T. Hunter, and M. Karin. 1988. Oncogene jun encodes a sequence-specific trans-activator similar to AP-1. Nature 332: $166-171$.

Angel, P., M. Imagawa, R. Chiu, B. Stein, R.J. Imbra, H.J. Rahmsdorf, C.J.P. Herrlich, and M. Karin. 1987. Phorbol ester-inducible genes contain a common cis element recognized by a TPA-modulated trans-acting factor. Cell 49: 729-739.

Beach, D. and P. Nurse. 1981. High frequency transformation of the fission yeast Schizosaccharomyces pombe. Nature 290: $140-142$.

Beach, D., M. Piper, and P. Nurse. 1982. Construction of Schizosaccharomyces pombe gene bank in a yeast bacterial shuttle vector and its use to isolate genes by complementation. Mol. Gen. Genet. 187: 326-329.

Bishop, J.M. 1985. Viral oncogenes. Cell 42: 23-38.

Booher, R.N., C.E. Alfa, J.S. Hyams, and D.H. Beach. 1989. The fission yeast $c d c 2 / c d c 13 /$ suc1 protein kinase: Regulation of catalytic activity and nuclear localization. Cell 58: 485497.

Bohmann, D., T.J. Bos, A. Admon, T. Nishimura, P.K. Vogt, and R. Tjian. 1987. Human proto-oncogene c-jun encodes a DNA binding protein structural and functional properties of transcription factor AP-1. Science 238: 1386-1392.

Boulton, T.G., G.D. Yancopoulos, J.S. Gregory, C. Slaughter, C. Moomaw, J. Hsu, and M.H. Cobb. 1990. An insulin-stimulated protein kinase similar to yeast kinases involved in cell cycle control. Science 249: 64-67.

Brown, M.S. and J.L. Goldstein. 1980. Multivalent feedback regulation of HMG-CoA reductase, a control mechanism coordinating isoprenoid synthesis and cell growth. I. Lipid Res. 21: $505-517$.

Cohen, P. 1989. The structure and regulation of protein phosphatases. Annu. Rev. Biochem. 58: 453-508.

Courchesne, W.E., R. Kunisawa, and J. Thorner. 1989. A putative protein kinase overcomes pheromone-induced arrest of cell cycling in S. cerevisiae. Cell 58: 1107-1119.

Edelman, A.M., D.K. Blumenthal, and E.G. Krebs. 1987. Protein serine/threonine kinases. Annu. Rev. Biochem. 56: 567613.

Elion, E.A., P.L. Grisafi, and G.R. Fink. 1990. FUS3 encodes a $c d c 2^{+} / C D C 28$-related kinase required for the transition from mitosis into conjugation. Cell 60: 649-664.

Elledge, S.J., and R.W. Davis. 1987. Identification and isolation of the gene encoding the small subunit of ribonucleotide reductase from Saccharomyces cerevisiae: A DNA damage-inducible gene required for mitotic viability. Mol. Cell. Biol. 7: 2783-2793.

Fried, M. and D.M. Crothers. 1981. Equilibria and kinetics of lac repressor-operator interactions by polyacrylamide gel electrophoresis. Nucleic Acids Res. 9: 6505-6525.

Gentz, R., F.J. Rauscher III, C. Abate, and T. Curran. 1989. Parallel association of Fos and Jun leucine zippers juxtaposes DNA binding domains. Science 243: 1695-1699.

Grimm, C., J. Kohli, J. Murray, and K. Maundrell. 1988. Genetic engineering of Schizosaccharomyces pombe: A system for gene disruption and replacement using the ura4 gene as a selectable marker. Mol. Gen. Genet. 215: 81-86.

Gutz, H., H. Heslot, U. Leupold, and N. Loprieno. 1974. Schizosaccharomyces pombe. In Handbook of genetics (ed. R.C. King), pp. 395-446. Plenum Press, New York.

Hagan, I.M. and J.S. Hyams. 1988. The use of cell division cycle mutants to investigate the control of microtubule distribution in the fission yeast Schizosaccharomyces pombe. I. Cell Sci. 89: 343-357.

Hanks, S.K., A.R. Quinn, and T. Hunter. 1988. The protein kinase family: Conserved features and deduced phylogeny of the catalytic domains. Science 241: 42-52.

Harshman, K.D., W.S. Moye-Rowley, and C. Parker. 1988. Transcriptional activation by the SV40 AP-1 recognition element in yeast is mediated by a factor similar to AP-1 that is distinct from GCN4. Cell 53: 321-330.

Hattori, M. and T. Sakaki. 1986. Dideoxy sequencing method using denatured plasmid templates. Anal. Biochem. 152: $232-238$.

Henikoff, S. 1984. Unidirectional digestion with exonuclease III creates targeted breakpoints for DNA sequencing. Gene 28: $351-359$.

Hirano, T., Y. Hiraoka, and M. Yanagida. 1988. A temperaturesensitive mutation of the Schizosaccharomyces pombe gene nuc2 ${ }^{+}$that encodes a nuclear scaffold-like protein blocks spindle elongation in mitotic anaphase. $J$. Cell Biol. 106: $1171-1183$.

Hurst, H.C. and N.C. Jones. 1987. Identification of factors that 
interact with the E1A-inducible adenovirus E3 promoter. Genes Dev. 1: 1132-1146.

Ito, H., Y. Fukuda, K. Murata, and A. Kimura. 1983. Transformation of intact yeast cells treated with alkali cations. $I$. Bacteriol. 153: 163-168.

Jones, R.H., S. Moreno, P. Nurse, and N.C. Jones. 1988. Expression of the SV40 promoter in fission yeast: Identification and characterization of an AP-1- like factor. Cell 53: 659667.

Kouzarides, T. and E. Ziff. 1988. The role of the leucine zipper in the fos-jun interaction. Nature 336: 646-651.

Laemmli, U.K. 1970. Cleavage of structural proteins during the assembly of the head bacteriophage T4. Nature 227: 680685.

Landschulz, W.H., P.F. Johnson, and S.L. McKnight. 1988. The leucine zipper: A hypothetical structure common to a new class of DNA binding proteins. Science 240: 1759-1764.

Lee, W., P. Mitchell, and R. Tjian. 1987. Purified transcription factor AP-1 interacts with TPA-inducible enhancer elements. Cell 49: 741-752.

Lee, M.G. and P. Nurse. 1987. Complementation used to clone a human homolog of the fission yeast cell cycle control gene cdc2 ${ }^{+}$. Nature 327: 31-35.

Levin, D.E., F.O. Fields, R. Kunisawa, J.M. Bishop, and J. Thorner. 1990. A candidate protein kinase C gene, $P K C 1$, is required for the S. cerevisiae cell cycle. Cell 62: 213-224.

Maniatis, T., E.F. Fritsch, and J. Sambrook. 1982. Molecular cloning: A laboratory manual. Cold Spring Harbor Laboratory, Cold Spring Harbor, New York.

Mitchison, J. M. 1970. Physiological and cytological methods for Schizosaccharomyces pombe. Methods Cell Physiol. 4: $131-165$.

1988. Synchronous cultures and age fractionationon. In Yeast: A practical approach. (ed. I. Campbell and I.H. Duffus), pp. 51-63. IRL Press, Oxford and Washington, D.C.

Mitchison, J.M. and P. Nurse. 1985. Growth in cell length in the fission yeast Schizosaccharomyces pombe. I. Cell Sci. 75: $357-376$.

Moreno, S., J. Hayles, and P. Nurse. 1989. Regulation of p34 cdc2 protein kinase during mitosis. Cell 58: 361-372.

Moye-Rowley, W.S., K.D. Harshman, and C. Parker. 1989. Yeast YAP1 encodes a novel form of the jun family of transcriptional activator proteins. Genes Dev. 3: 283-292.

Nakano, H., E. Kobayashi, I. Takahashi, T. Tamaoki, Y. Kuzuu, and $\mathrm{H}$. Iba. 1987. Staurosporine inhibits tyrosine-specific protein kinase activity of Rous sarcoma virus transforming protein p60. I. Antibiot. 40: 706-708.

Nasmyth, K.A. and S.I. Reed. 1980. Isolation of genes by complementation in yeast: Molecular cloning of a cell cycle gene. Proc. Natl. Acad. Sci. 77: 2119-2123.

Nishizuka, Y. 1986. Studies and perspectives of protein kinase C. Science 233: 305-310.

Nurse, P. 1990. Universal control mechanism regulating onset of M-phase. Nature 344: 503-508.

Ogita, K., S. Miyamoto, H. Koide, T. Iwai, M. Oka, K. Ando, A. Kishimoto, K. Ikeda, Y. Fukami, and Y. Nishizuka. 1990. Protein kinase C in Saccharomyces cerevisiae; comparison with mammalian enzyme. Proc. Natl. Acad. Sci. 87: 50115015.

Ohkura, H., N. Kinoshita, S. Miyatani, T. Toda, and M. Yanagida. 1989. The fission yeast dis $2^{+}$gene required for chromosome disjoining encodes one of two putative type I protein phosphatases. Cell 57: 997-1007.

Omura, S., Y. Iwai, A. Hirano, A. Nakagawa, J. Awaya, H. Tsuchiya, Y. Takahashi, and R. Masuma. 1977. A new alkaloid AM-2282 of Streptomyces origin taxonomy, fermentation, isolation and preliminary characterization. I. Antibiot. 30: $275-282$.

Rosenberg, A.H., B.N. Lade, D.-S. Chui, S-W. Lin, J. J. Dunn, and F.W. Studier. 1987. Vectors for selective expression of cloned DNAs by T7 RNA polymerase. Gene 56: 125-135.

Rothstein, R.J. 1983. One-step gene disruption in yeast. Methods Enzymol. 101: 202-211.

Russell, P.R., and B.D. Hall. 1983. The primary structure of the alcohol dehydrogenase from the fission yeast Schizosaccharomyces pombe. J. Biol. Chem. 258: 143-149.

Sanger, F., S. Nicklen, and A.R. Coulson. 1977. DNA sequencing with chain-terminating inhibitors. Proc. Natl. Acad. Sci. 74: 5463-5467. Streiblova, E. and A. Wolf. 1972. Cell wall growth during the cell cycle of Schizosaccharomyces pombe. Z. Allg. Mikrobiol. 12: 673-684.

Studier, F.W. and B.A. Moffatt. 1986. Use of bacteriophage T7 RNA polymerase to direct selective high-level expression of cloned genes. J. Mol. Biol. 189: 113-130.

Tamaoki, T., H. Nomoto, I. Takahashi, Y. Kato, M. Morimoto, and F. Tomita. 1986. Staurosporine, a potent inhibitor of phospholipid $/ \mathrm{Ca}^{++}$dependent protein kinase. Biochem. Biophys. Res. Commun. 135: 397-402.

Toda, T. and M. Yanagida. 1988. Genetic analyses of fission yeast mutants super-sensitive to the inhibitors of protein $\mathrm{ki}$ nase C. J. Cell. Biol. 107: 720a.

Towbin, H., T. Staehein, and J. Gordon. 1979. Electrophoretic transfer of proteins from polyacrylamide gels to nitrocellulose sheets: A procedure and some applications. Proc. Natl. Acad. Sci. 76: 4350-4354.

Turner, R. and R. Tjian. 1989. Leucine repeats and an adjacent DNA binding domain mediate the formation of functional cFos-cJun heterodimers. Science 243: 1689-1694.

Uemura, T. and M. Yanagida. 1984. Isolation of type I and II DNA topoisomerase mutants from fission yeast: Single and double mutants show different phenotypes in cell growth and chromatin organization. EMBO J. 3: 1737-1744.

van Straanten, F., R. Muller, T. Curran, C. van Beveren, and I.M. Verma. 1983. Complete nucleotide sequence of human $c$-onc gene: Deduced amino acid sequence of the human c-fos protein. Proc. Natl. Acad. Sci. 80: 3183-3187.

Vinson, C.R., P.B. Sigler, and S.L. Mcknight. 1989. Scissors-grip model for DNA-recognition by a family of leucine zipper proteins. Science 246: 911-916.

Vogt, P.K., T.J. Bos, and R.F. Doolittle. 1987. Homology between the DNA- binding domain of the GCN4 regulatory protein of yeast and the carboxy-terminal region of a protein coded for by the oncogene, jun. Proc. Natl. Acad. Sci. 84: 3316-3319.

Watt, R.A., A.R. Shatzman, and M. Rosenberg. 1985. Expression and characterization of the human c-myc DNA-binding protein. Mol. Cell. Biol. 5: 448-456.

Yanisch-Perron, C., C. Vieira, and J. Messing. 1985. Improved M13 phage cloning vectors and host strains: Nucleotide sequences of the M13 mp18 and pUC vectors. Gene 33: 103119.

Zenke, M., T. Grundstrom, H. Matters, M. Wintzerith, C. Schatz, A. Wideman, and P. Chambon. 1986. Multiple sequence motifs are involved in SV40 enhancer function. EMBO I. 5: 387-397. 


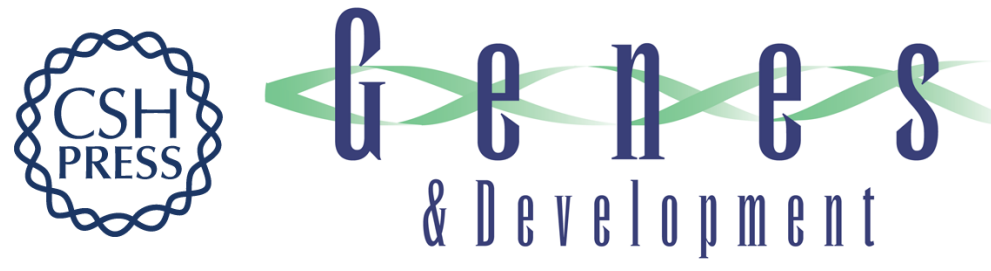

\section{Fission yeast genes that confer resistance to staurosporine encode an AP-1-like transcription factor and a protein kinase related to the mammalian ERK1/MAP2 and budding yeast FUS3 and KSS1 kinases.}

T Toda, M Shimanuki and M Yanagida

Genes Dev. 1991, 5:

Access the most recent version at doi:10.1101/gad.5.1.60

References This article cites 60 articles, 24 of which can be accessed free at: http://genesdev.cshlp.org/content/5/1/60.full.html\#ref-list-1

License

Email Alerting Service

Receive free email alerts when new articles cite this article - sign up in the box at the top right corner of the article or click here.

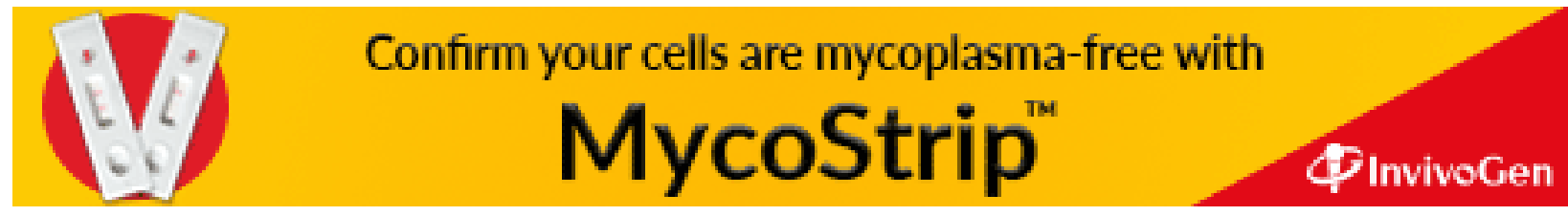

